\title{
Characteristic of Birds of Prey Migration in the Kharkov Region, Ukraine
}

\section{ОСОБЕННОСТИ МИГРАЦИИ ХИЩНЫХ ПТИЦ В ХАРЬКОВСКОЙ ОБЛАСТИ, УКРАИНА}

\author{
Viter S.G. (National nature park "Gomilshansky Lisy", Kharkiv region, Ukraine) \\ Витер С.Г. (Национальный природный парк «Гомольшанские леса», Харьковская \\ область, Украина)
}

\section{Контакт: \\ Станислав Витер \\ Национаиьный природный парк "Гомольшанские леса" 61077, Украина, Харьков, пи. Свободы, 4 viter_stanislav@ukr.net}

\section{Contact:}

Stanislav Viter

National Park

"Gomilshansky Lisy"

Svobody sq., 4

Kharkov, Ukraine, 61077

viter_stanislav@ukr.net

\section{Резюме}

В Аанной статье рассмотрены особенности миграционного процесса хишных птиц (Accipitriformes и Falconiformes) в условиях равнинных ландшастов Восточной Европы. Нами исследованы такие вопросы, как видовой состав мигрируюших хишных птиц, их численность и ее динамика по годам, биотопическое распределение останавливаюшихся на миграции пернатых хишников, высота и направление миграционных перемещений, состав и численность мигрируюших групп, территориамьное распределение - особо важные территории как места отдыха, основные угрозы. Исследования проводияи на территории, в пределах которой нет действия факторов, приводящих к эсрфекту “бутылочного горлышка». Естественным мяя большинства видов хишных птиц является перемешение в одиночку или парами, реже - небольшими группами, и только при стечении ряда неблагоприятных фракторов сормируются крупные скопления - стаи. Наиболее многочисленный вил - обыкновенный канюк (Buteo buteo): на его Аолю приходится около 41,8 \% всех особей мигрируюших хишных птиц. К субдоминантам (от 7-8 \% до $15 \%$ можно отнести зимняка (Buteo lagopus), перепелятника (Accipiter nisus), осоела (Pernis apivorus) и чеглока (Falco subbuteo). Обычные виды - малый подорлик (Aquila pomarina), орёл-карлик (Hieraaetus pennatus) и болотный мунь (Circus aeruginosus). Численность большинства видов относительно стабильна, год Аепрессии численности - 2013. В 2015 году наблюдали рост численности змееяла (Circaetus gallicus) и обыкновенного канюка, в 2016 - скопы (Pandion haliaetus), а в 2008-2010 гг. - осоеда. Преоблахающее направление осенних перемещений - юго-восток и юг, много зимняков перемещаются в запацном направлении. Весной чаше всего наблюдами птиц, летящих на северо-восток, реже - север и северозапал. Большинство транзитных особей отмечены на мамых и средних высотах - $\Delta$ о 150 метров. Орлы (Аquіla) распределены равномерно на всех диапазонах высот со значительной Аолей птиц, летящих на высотах от 350 Ао 600 м и выше. В период с 2007 г. по 2016 г. сАвинулись Ааты массовой осенней миграции, а также начаиа осенней миграции на более ранние сроки (в среднем - разница составляет 10-14 дней).

Киючевые слова: хищные птицы, миграции, биотопы, направление миграции, численность и состав групп мигрируюших птиц.

Поступияа в редакцию: 27.10.2017 г. Принята к публикации: 30.03 .2018 г.

\section{Abstract}

This article describes the characteristic of the raptor's (Accipitriformes, Falconiformes) migration through Eastern European plains. We studied issues of a species distribution, number of migrants including between years variations, biotopical preferences, altitude and directions of migration, species composition and strength of migratory groups, important migration, and resting areas, and main threats. Studies were carried out on the territory without "bottleneck" factors. Most species migrate through the Eastern European plain as a sole individual or in pairs, more rarely - in small groups of 2-5 birds. In adverse circumstances, raptors can aggregate in big numbers making flocks. The most numerous species on migration is Common Buzzard (Buteo buteo) - a dominant species: $41.8 \%$ of all birds of prey observed on migration are Common Buzzards. Subdominant species (from 7-8 \% to $15 \%)$ are Rough-legged Buzzard (Buteo lagopus), Eurasian Sparrowhawk (Accipiter nisus), Honey Buzzard (Pernis apivorus) and Northern Hobby (Falco subbuteo). Other common species are Lesser Spotted Eagle (Aquila pomarina), Booted Eagle (Hieraaetus pennatus), and Marsh Harrier (Circus aeruginosus). The number of migrating individuals for most species can be characterized as stable with overall depression in 2013. In 2008-2010 we observed the growth of the number of migrating Honey Buzzards, in 2015 - Short-Toed Eagles (Circaetus gallicus) and Common Buzzards, and in 2016 - Ospreys (Pandion haliaetus). The main directions of migratory movements in autumn are south-east and south; Rough-legged Buzzards are often moving to the west. In spring birds of prey are flying north-east and north, and less often - north-west. Most of the transit birds of prey were observed at low and middle altitudes (up to $150 \mathrm{~m}$ ). Eagles (Aquila genus) are distributed more evenly with a significant number of high altitude migrants (from 350 to 600 m and higher). From 2007 to 2016 we observed shifts to the earliest dates in autumn migration start and peak. The average shift was 10-14 days.

Keywords: birds of prey, migration, biotope, direction of migration, species composition, number of migrating individuals.

Received: 27/10/2017. Accepted: 30/03/2018.

\section{Введение}

Миграции птиц, в том числе хишных (Accipitriformes, Falconiformes), в «Старом Свете" были хорошо изучены в Запанной Европе, Асрике, в Южной, Юго-Восточ-

\section{Materials and methods}

The area under study covers the southern part of Eastern European plain in the administrative borders of Kharkiv region of Ukraine. Landscapes are diverse and include 
ной и Восточной Азии (Fergusson-Lees, Christie, 2006; Allen, DeCandido, 2007; Newton, 2008; BRC, 2017). Чаше всего такие наблюдения проводили в «бутылочных горлышках" на миграционных путях - в местах, гле по стечению ряла естественных условий скиадывалась особая ситуация, а именно - концентрация большого количества мигрируюших птиц в пределах очень ограниченной территории. Основные цели таких исследований лежами в плоскости многолетнего мониторинга численности мигрируюших видов и сроков миграции, изучения демограсрии (соотношение половозрастных групп) (Allen, DeCandido, 2007; Birding Cadiz Province, 2017; BRC, 2017). ОАновременно в таких местах, гле наблюдается вынужденная концентрация мигрируюших птиц и гАе сам процесс миграции проходит в максимамьно сжатые

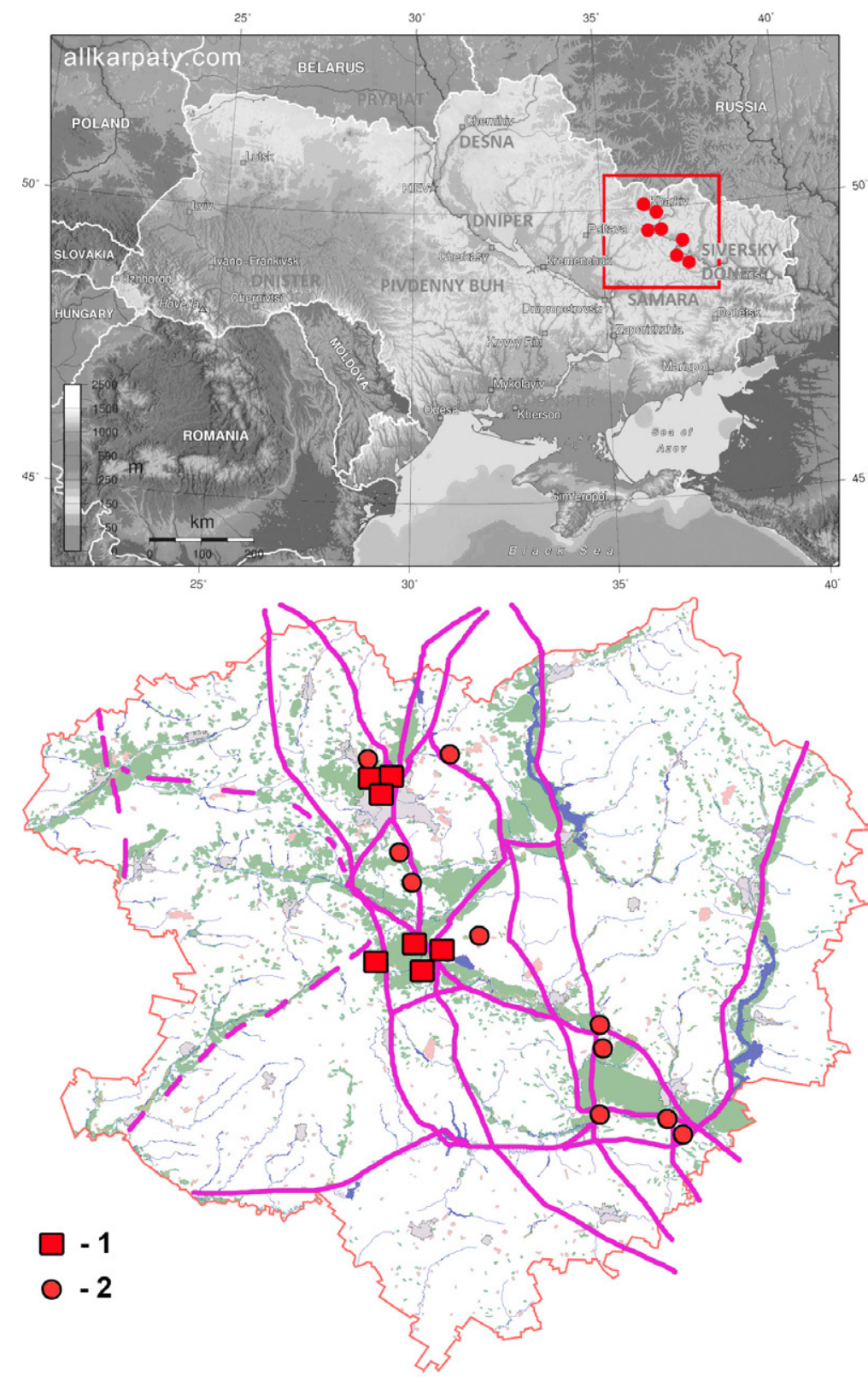

the southern part of European forest-steppe natural zone (meadows and northern types of steppes, upland oak forests, wetlands in river valleys and agrarian territories) and the northern part of European steppe zone. A small part of the area is located on the northern-west spurs of Donetsk range and on the eastern outskirts of Poltava plane (a part of the Dnieper lowland). In the valley of the Seversky Donets, there are extensive sections of loess terraces forming a river valley up to $68 \mathrm{~km}$ width (Integrated atlas of Ukraine, 2005).

Main observation points are located in the National Nature Park "Gomilshansky Lisy” (Seversky Donets river valley with oak forests; flooded forests dominated by oaks, alders, and willows; pine forests growth on sands; fields, meadows, and steppes) and near Kharkiv city (agricultural landscapes with settlements and native biotopes). Observation points are displayed in fig. 1 .

The research was conducted in 20032016. During this period, observations were carried out annually, from August 1 to November 1 , the observation days were evenly distributed throughout the entire period of autumn raptors migration. At least $25 \%$ of the time of autumn migration was covered by observations every season, but in 2012-2016 it was at least $30 \%$. Special attention was paid to the periods of severe deterioration of weather conditions (strong winds, severe precipitation), resulting in extra observation days ( 3 days before and 2-3 days after the weather deterioration). In more northerly regions (as far as $55^{\circ} \mathrm{N}$ ) observations were carried out during such periods as well, plus 3-5 days after.

Observations were carried out from 10 am to $5 \mathrm{pm}$ on 2-3 observation points by a group of observers (groups from 2 to 20 persons). We used field binoculars $(\times 8)$ and spotting scopes $(20 \times 60)$. The distance to a bird and flight altitude was measured by means of a rangefinder (Halo XRT62).
Рис. 1. Места наблюдения за миграциями хищных птиц: 1 - места регулярного мониторинга, 2 - места нерегулярных наблюдений; минии - основные пути миграционных перемешений хишных птиц по территории Харьковской области.

Fig. 1. Observation points for migrating birds of prey monitoring: 1 - sites of regular monitoring, 2 - sites of non-regular monitoring; lines -main migratory routes of birds of prey in Kharkiv region. 
сроки, нет возможности говорить о изучении самого процесса миграционных перемешений и его видоспецисических характеристиках. Как правило, в таких «бутылочных горлышках" птицы вынужАенно концентрируются на ограничен-

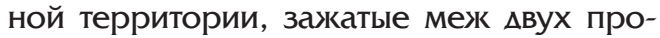
странств воды (морей) или межАу морским побережьем и бескрайними выжженными солнцем пустынями. Это приводит к изменению таких параметров, как численность миграционных групп, высота и скорость, а иногда - и направление перемешений, прочее (Allen, DeCandido, 2007; Newton, 2008; Birding Cadiz Province, 2017; BRC, 2017; данные наблюдений автора в Грузии). Следовательно, только в условиях равнин с умеренными природными условиями можно наблюдать естественный мя каждого конкретного вида ход миграции. В Западной Палеарктике такие идеамьные условия скиацываются на обширных равнинах Восточной Европы, которая пока что остаётся регионом, гАе миграции хишных птиц изучены крайне недостаточно, а $\Delta$ о недавнего времени отсутствоваи системный сбор данных и многолетний мониторинг.

В 2007 году нами начат ежегодный мониторинг миграционного процесса хищных птиц на территории Харьковской области (Украина), целиком лежашей в пределах Восточноевропейских равнин и умеренно-континентаиьного киимата европейских степей и лесостепей. В пределах данного региона отсутствуют пустынные территории, горные массивы, обширные водные пространства и прочие объекты, которые могут создавать условия «бутылочного горлышка" и искажать видоспецисрический ход миграции.

Цель исследования: изучить особенности миграционного процесса хишных птиц (прежле всего - в осенний периол) в равнинных регионах Восточной Европы.

Задачи исследования:

- проведение учётов и мониторинга численности мигрируюших хишных птиц;

- изучение характеристик миграционных перемешений (высота, направление);

- изучение биотопического распределения мигрируюших птиц, отличия межАу виАами;

- определение статуса мигрантов, соотношения численности групп по статусу, отмичия межАу видами;

- изучение распределения миграционных волн разных виАОв хишных птиц по месяцам и Аням;

- изучение структуры групп мигрирую-
For obtaining data on weather conditions and the weather forecast, air traffic maps, snow cover height, etc. we used an information from meteorological websites ${ }^{85,86,87,88,89,90,91}$.

Additional observations were carried out in November, December and beginning of January to observe the migration of Rough-legged Buzzards caused by significant changes in snow layer - up to $10 \mathrm{~cm}$. Observations took place both in the main region of study and in more northerly regions (as far as $55^{\circ} \mathrm{N}$ ). These observations were associated with heavy snowfalls in the region between $50^{\circ}$ and $52^{\circ} \mathrm{N}$ and $34^{\circ}$ and $40^{\circ} \mathrm{E}$ (studying the movements of Roughlegged Buzzards (Buteo lagopus) on the next day after the snowfall), and in the region between $52^{\circ}$ and $55^{\circ} \mathrm{N}$ and $36^{\circ}$ and $42^{\circ} \mathrm{E}$ (studying the movements of Roughlegged Buzzards on the second day after significant changes in the snow cover).

Observations during the spring migration were not so evenly distributed throughout the migration period and cover $20-25 \%$ of the migration period, mainly in the middle of April - early May.

During observations we recorded the following parameters: status of a bird / group of birds (transit, stopover during migration, vagrant), direction of migration (north, south, west, east and intermediate points - 16 points in total), altitude (low, low - average, average, average - high, high, very high), number of individuals, group composition (species forming a group of migratory birds), habitats.

In total, we got 1393 records/observations of raptor's migration. The total number of observed individuals was 2368 birds belonging to 27 species (see Annex $\mathbf{1}^{\mathbf{9 2}}$ ).

Visualization of the results and statistical processing were performed in R 3.4 (R Core Team, 2016). Plots and diagrams are performed via "Ggplot2" and "Corrplot" packages for R (Wickham, 2009; Wei, Simko, 2016).

\section{Terms}

1. Status:

- a transit migrant - is a specimen that has not been recorded before or after the observation, and moving in a direction that correlates with the directions of migration during the given season a priori (for the autumn period - south, southwest, southwest-south, west-south-west, west, east, east-south-east, south-east, south-eastsouth directions);

- nomadic - is a specimen observed in a limited time period beyond the breeding 
ших птиц (число особей в группе, количество мигрантов в группах и одиночек, виАОвой состав поливиАовыХ групп);

- изучение фенологии миграционной активности разных виАов хишных птиц;

- выявление территорий, важных как места отдыха мигрируюших хишных птиц;

- изучение потенциамьных угроз мяя мигрируюших птиц в пределах Харьковской области.

\section{Материамы и методы}

Регион исследования лежит в пределах Восточноевропейской возвышенности (Среднерусская возвышенность), охватывая ее южные отроги в пределах Харьковской области (Украина). Местность представляет собой ярусную наклонную равнину, местами - с элементами увамистого рельесра, пересеченную ярами (на

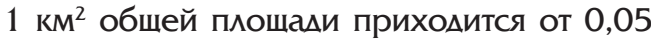
Ао 1 км яров). В ландшастном плане территория представлена южной европейской месостепью (разнотравные муговые степи, нагорные Аубравы, водно-болотные уголья речных Аолин и агроландшафты на месте луговых степей), а также формациями северных степей. Небольшая часть региона расположена на северо-запанных отрогах Аонецкого Кряжа и на восточной перисерии Полтавской равнины (часть Приднепровской Низменности). В Аолине Северского $\Delta$ онца есть обширные участки лессовых террас, формируюших речную Аолину шириной $А$ 68 км (Комплексний атлас України, 2005).

Территория исследования лежит в пределах Северскодонецкого и $\Delta$ непро- $\Delta \mathrm{oH}^{-}$ ского миграционных коридоров, которые, однако, вылелены весьма условно, преимушественно на основании приуроченности мигрируюших водно-болотных птиц к Аолинам крупных рек. Аия миграционных перемешений хишных птиц характерно Авижение широким фронтом с некоторой концентрацией (прежле всего - подорликов) к Аолинам крупных рек, гАе численность мигрантов массовых видов на 30-50 \% превышает аналогичные показатели мия водоразделов.

Основные наблюдательные пункты расположены в Национаиьном природном парке "Гомольшанские леса" (пойма Северского Аонца, граница речной Аолины, полей, степных участков и дубрав на коренном берегу, боровые массивы на песчаной террасе Северского Аонца), а также в окрестностях г. Харьков (жиммассив "Алексеевка" и $\Delta$ ергачевский район or migrating season; movements often do not have a pronounced orientation that corresponds to the direction of migration in a given season;

- stopover on migration - an individual that was absent during the breeding, wintering and premigration period; its movements do not have a pronounced orientation; the bird remains in the given locality for at least one night.

2. Flight altitude:

- low - up to $50 \mathrm{~m}$ from the ground;

- low / average height: from 50 to $100 \mathrm{~m}$;

- average height: from 100 to $150 \mathrm{~m}$;

- average height / high: from 150 to 200 m;

- high: from $200 \mathrm{~m}$ to $500 \mathrm{~m}$;

- very high: more than $500 \mathrm{~m}$.

\section{Results and discussion}

1. Species composition and a number of migratory raptors

The total number of migrating species registrations is 1393; in one registration it could be more than one bird, and in total, we recorded 2368 individuals that belong to 27 species (+ a group of Spotted Eagles not identified to the species).

The dominant species on migration according to the number of registrations is a Common Buzzard (Buteo buteo) - 451 registrations (32.4\% of all migrant birds of prey registrations). Subdominant species are Rough-legged Buzzard (Buteo lagopus) with 201 registrations (14.43\%), Honey Buzzard (Pernis apivorus) - with 140 (10.05\%) and Eurasian Hobby (Falco subbuteo) - with 147 (10.55\% of total). Species that have not less than $3 \%$ of all migrant birds of prey registrations can be classified as common. These are species like Booted Eagle (Hieraaetus pennatus) with 51 registrations (3.66\%) and Eurasian Sparrowhawk (Accipiter nisus) with 65 registrations (4.66\%). Next to them are Lesser (Aquila pomarina) and Greater (Aquila clanga) Spotted Eagles: 39 ( $2.8 \%$ of total) and 34 ( $2.4 \%$ of total) registrations respectively, plus several Spotted Eagles were not identified to the species (21 registrations or $1.51 \%)$. The other species are rare or not numerous: Levant Sparrowhawk (Accipiter brevipes) - 10 registration, Eastern Imperial Eagle (Aquila heliaca) - 13, Golden Eagle ( $A$. chrysaetos) - 7, Steppe Eagle (A. nipalensis) - 3, Long-legged Buzzard (Buteo rufinus) - 11, Short-toed Eagle (Circaetus gallicus) - 7, Marsh harrier (Circus aeruginosus) - 35, Hen Harrier (C. cyaneus) - 24, Pallid Harrier (C. macrourus) 10, Montagu`s Harrier (C. pygargus) -17 , 
Харьковской области, преимушественно поля с вкАючениями населенных пунктов и естественных биотопов). Наблюдательные пункты отображены на рис. 1.

Исследования проводили в 2003-2016 годах. Основное внимание уделяли учетам и изучению особенностей миграции хищных птиц в осенний период в 2007-2016 годах. В этот период наблюдения провоцили ежегодно, с 1 августа по 1 ноября. $\Delta$ ни наблюдений были равномерно распределены в течение всего периода осенней миграции и охватываяи не менее $25 \%$ времени, пригодного мия миграционных перемешений основных целевых видов птиц-парителей среднего и крупного размерного киасса. В период с 2012 по 2016 гг. наблюдениями охватывами не менее $1 / 3$ всего периода осенней миграции. Помимо равномерно распределенных дней наблюдений, внимание уделяли дням перед сильным ухудшением погоды на срок не менее 3 суток, а также 2-3 дням после такого периода ухудшения погодных условий (сильные ветры, обложные осалки) и периоду, соответствуюшему резкому ухудшению погодных условий (+ 3-5 дней по истечению такого периода) в более северных регионах - $о$ о уровня $55^{\circ}$ с.ш.

Наблюдения проводили С 10.00 Ао 17.00 , на 2-3 точках; в учетах принимами участие от 2 мо 20 человек. Использовами полевые бинокии (8 крат) и подзорные трубы (20×60), расстояние $А$ птиц и высоту определяли с использованием Аальномеров (Halo XRT62).

$\Delta$ ия получения Аанных о прогнозе погоды в разных регионах на срок $\Delta о 1$ нелели использовали инсормацию различных метеосайтов $85,86,87,88,89,90,91$ - как собственно прогноз погоды, так и карты движения возАушных масс, высоты снежного покрова и т.п. Аополнительно проводили наблюдения за перемешениями зимняков (Buteo lagopus) в ноябре - декабре - начале января, связанными со значительным (на 10 см) - изменением глубины снежного покрова, как в районе проведения исследований, так и в более северных регионах (на север $\Delta$ о $55^{\circ}$ с.ш.). Такие наблюдения были увязаны с сильными снегопадами в регионе межау $50^{\circ}$ и $52^{\circ}$ с.ш. и $34^{\circ}$ и $40^{\circ}$ в.А. (наблюдаяи кочевки зимняков на следуюший день после выпадения снега), а также в регионе межлу $52^{\circ}$ и $55^{\circ}$ с.ш. и

http://sinoptik.ua

s6 http://www.nemiga.info/pogoda-minsk.htm

87 http://cosmos-online.ru

$s 8$ http://ww1.sea-weather.com
White-Tailed Eagle (Haliaeetus albicilla) - 5, Black Kite (Milvus migrans) - 26, Osprey (Pandion haliaetus) - 14, Saker (Falco cherrug) - 9, Gyrfalcon (F. rusticolus) - 1, Merlin (Falco columbarius) - 9, Common Kestrel (F. tinnunculus) - 20, Red-footed Falcon ( $F$. vespertinus) - 11 registrations (fig. 2).

We should note that for some raptor species it was difficult to separate local birds from migrant ones. Especially in case of Eurasian Sparrowhawk in spring, and Black Kites, Marsh Harriers, White-Tailed Eagles and Common Kestrels in agrarian landscapes during both migration seasons. For these species, we recorded only transit birds flying high in the right direction whose migrating was apparent, thus the number of registrations, as well as the number of individuals (see below) for these species could be significantly underestimated.

Analysis of the total number of counted individuals $(n=2368)$ gives us the following results: the dominant species is a Common Buzzard - 989 specimens or $41.7 \%$ of the total. This result significantly exceeds the percentages obtained for the same species counted by registrations. And same could be seen for Rough-Legged (294 specimens, or $12.42 \%$ ) and Honey Buzzards (363 specimens or $15.33 \%)$. It is due to the fact that all three species often migrate in small groups rather than alone. Subdominant species are Honey Buzzard, Rough-legged Buzzard, and Eurasian Hobby (180 specimens or $7.6 \%)$. Common species based on the number of birds are Booter Eagle, Eurasian Sparrowhawk, Lesser Spotted Eagle and Common Kestrel (for more details see table 1).

\section{Migrations in groups: numbers and species}

In the area of the study most birds of prey are solitary on migration; less often they could form family groups, and occasionally - mixed flocks (see table 2). This behavior is strikingly different from what one could see on territories where birds have to pass through bottlenecks along migration corridors like in Gibraltar, Batumi (Georgia) or Chumphon (Thailand) (Allen, DeCandido, 2007; Birding Cadiz Province, 2017; BRC, 2017).

Nine out of 27 species are strictly solitary migrants. Two Harrier species (Montagu's and Pallid) are solitary on transit movements but they readily gather in groups of

\footnotetext{
89 http://meteoinfo.ru

9o http://www.weatheronline.co.uk
}

91 http://www.gismeteo.ua 
$36^{\circ}$ и $42^{\circ}$ в.А. (на вторые сутки после значительного изменения снежного покрова).

Наблюдения в период весенней миграции не были столь равномерно распредемены в течение всего периода миграции, охватываяи 20-25 \% миграционного периода, преимушественно в средине апреля начале мая.

В ходе наблюдений отмечали: статус птиц (транзитные, останавливаюшиеся на миграции, кочуюшие), направление перемешения (север, юг, запад, восток и промежуточные румбы межАу этими основными и полурумбами - всего 16 румбов), высота перемешения (низко, низко - средняя высота, средняя высота, средняя высота - высоко, высоко, очень высоко), количество особей, состав группы (виды, образуюшие группу мигрируюших птиц), биотопы.

Аия некоторых видов (обыкновенный канюк Buteo buteo, осоед Pernis apivorus, зимняк) использоваии систему индивиАуального распознавания - по особенностям окраски: обший тон светлых участков оперения, интенсивность развития темных тонов на нижнем контурном оперении, особенности консигурации пятна на нижней части сгиба крыла, полос и пестрин на нижних кроюших крыла и т.п.

Размер выборки составил 1393 регистраций/наблюдений за перемешением хишных птиц. Общее количество наблюАаемых особей составило 2368, принацлежаших к 27 видам (см. Приложение $1^{92}$ ).

Визуализацию результатов и статистическую обработку проводили в среде R 3.4 (R Core Team, 2016). Значимость отличий в составе групп и статусе пребывания мигрируюших подорликов тестировали при помоши точного критерия Фишера м^я таблиц сопряженности (Шамрай, ЗаАорожний, 2010). Взаимосвязь межАу переменными тестировами при помоши коэсфициента ранговой корреляции Кендемла ( $T$ ) мия попарных сравнений и коэсфрициента ранговой корреляции Спирмена мяя множественных сравнений (Кабаков, 2014). Грасики и диаграммы выполнены с использованием пакетов ggplot2 и corrplot мяя R (Wickham, 2009; Wei, Simko, 2016).

\section{Используемые термины}

1. Статус:

- транзитный мигрант - особь, которая достоверно не отмечена $\Delta о$ и после наблюдения, имеюшая в своем перемеше-
2-7 individuals to stay overnight. Most eagles migrate solitary except Booted Eagle and Lesser Spotted Eagle who seldom migrate in groups or in pairs. Booted Eagles were seen migrating in groups or pairs in $15.7 \%$ of registrations and Lesser Spotted Eagles were seen migrating in pairs in 27.5 $\%$ and in a group in $2.5 \%$ of registrations (fig. 3). A unique case of registration of the group of Spotted Eagles (2 Greater SE and 4 Lesser SE) occurs on the eve of significant deterioration in weather conditions. Ospreys also prefer to migrate solitary making paired migration only in $14.3 \%$ of registrations (table 2).

Solitary migrants prevail even in species that are expected to be seen in groups such as Common Buzzard and Honey Buzzard. In Common Buzzard, $61.4 \%$ of registrations - are solitary birds, $17.3 \%$ - pairs, $8 \%$ groups of 3 birds, $3.1 \%$ and $3.3 \%$ are for groups of 4 and 5 birds respectively (table 2 ). The largest groups of migrant Common Buzzards include 14, 17 and 23 birds and were observed either on the 3rd decade of September or in the middle of October, which corresponds to a period of weather clearing replacing a large cyclone. In Honey Buzzards more than a half of registrations are registrations of sole birds (57.1\%), pairs were observed in $\mathbf{2 0 . 7} \%$ of cases, groups of 3 - in $7.8 \%$ and groups of 4 - in $3.57 \%$. The largest flocks of Honey Buzzards - 29, 30 and 31 individuals - were recorded on 26/08/2016 during the peak migration of the species in the period of weather clearing after prolonged heavy rainfalls.

Thus, making flocks on migration is not a characteristic feature for Common Buzzards and Honey Buzzards while passing through plain landscapes of temperate Eastern Europe. Flocks could be formed during autumn migration under certain circumstances such as sharp weather changes (end of precipitation, abrupt cooling) or conversely "hopelessness" in the weather - prolonged precipitation. As another cause, we can consider an abundant foraging base on harvested fields where raptors concentrate on stopovers during migration.

Another interesting feature of Accipitridae birds of prey is a making of mixed flocks consisting of several species. We got 73 registrations $(5.24 \%$ of the total number of 1389 registrations) from 34 mixed flocks involving 123 birds of prey (5.2\% of the total number of 2368 migrating birds of prey)

92 http://rrrcn.ru/wp-content/uploads/2018/03/ViterS1.xls 
нии четкое направление, априори корремируюшее с направлениями миграции в Аанный сезон (мяя осеннего периода это такие направления, как: юг, юго-запад, югзапал-юг, запац - юг - запац, запац, восток, восток - Юг - восток, Юго-восток, ЮГ - восTOK - Юг);

- кочуюший - особь, пребывание которой отмечено в ограниченный период вне основного периода как гнездования, так и миграции, перемешения часто не имеют выраженной направленности, соответствуюшей направлению миграции в Аанный сезон;

- останавливаюшийся на миграции особь, которая достоверно отсутствовала в период гнездования, зимовки и Аомиграционных перемешений, перемешения которой не имеют выраженной направленности, характерно пребывание в ханной местности как минимум с одной ночевкой.

2. Высота перемешения:

- очень низко - $о$ 50 м от земли;

- НИзко - От 50 Ао 100 м;

- средняя высота - от 100 до 150 м;

- умеренная высота - от 150 до 200 м;

- высоко - от 200 Ао 500 м;

- очень высоко - более 500 м.

\section{Результаты и обсужиение}

1. Вицовой состав и численность мигрирующих хишных птиц

Обшее количество наблюдений составило 1393, в ходе которых отмечена миграция 2368 особей, принамиежаших к 27 видам.

Из обшей выборки регистраций мигрируюших хишных птиц виАом-АОминантом является обыкновенный канюк - 451 регистрация (32,4 \% всех регистраций мигрируюших птиц). К субдоминантам можно отнести зимняка - 201 регистрация (14,43\%), а также осоела - 140 регистраций $(10,05 \%)$ и чеглока (Falco subbuteo) - 147 регистраций $(10,55 \%)$. К обычным видам можно отнести те виды, на Аолю которых приходится не менее $3 \%$ регистраций - это орёл-карлик (Hieraaetus pennatus) - 51 регистрация (3,66 \%) и ястреб-перепемятник (Accipiter nisus) - 65 регистраций (4,66 \%). Близки к Аостижению порога категории "обычный виА" также мамый (Aquila pomarina) и большой (A. clanga) подорлики: 39 и 34 регистрации соответственно (2,8 \% и 2,4\%), численность этих видов может быть увеличена за счет подорликов, не определённых $А$ вила (таких - 21 регистрация, или 1,51\%). Остамьные виды являются мамочисленными или редкими:

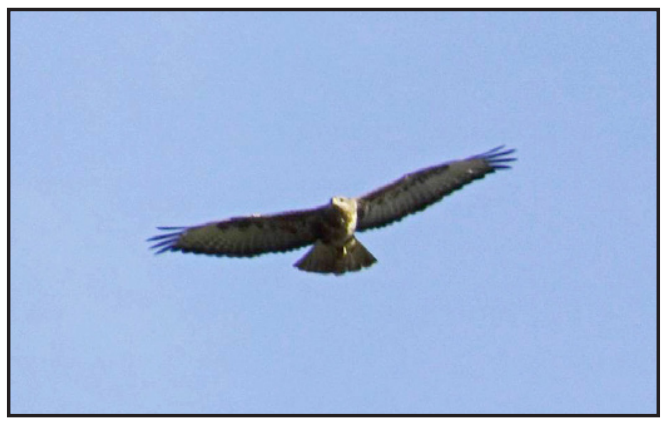

Канюк (Buteo buteo). Фото И. Козицкого.

Common Buzzard (Buteo buteo). Photo by I. Kozitsky.

from 15 out of 27 species (55.5\%). Three non-raptor species were also noted in this flocks: 24 Ravens (Corvus corax) in a group with 1 Common Buzzard; 1 Black Stork (Ciconia nigra) + 1 Common Buzzard; 1 Common Crane (Grus grus) + 1 Common Buzzard + 1 Spotted Eagle (supposedly Greater Spotted Eagle).

Lesser Spotted Eagle is a species most prone to join mixed groups - about $20 \%$ of all individuals of this species were found in mixed flocks. The percentage of Lesser Spotted Eagles in the total number of birds of prey in mixed flocks is $8.04 \%$.

The most numerous species among those from the mixed flocks is a Common Buzzard - it made about half of all birds of prey found in mixed flocks (58 out of 123 birds or $47.15 \%)$. This percentage is only slightly differing from the proportion of Common Buzzards in the total number of migrants (41.7\%) (see above). On the other hand, only $5.9 \%$ of all migrating Common Buzzards were found in mixed flocks, but the most of them were found in monospecies groups. Thus, we can conclude that this species is not prone to make a mixed flocks/ groups with other species. Nearly all cases of involvement of Common Buzzards into a mixed flock happened when other species joined a group of buzzards.

Honey Buzzards makes $7.32 \%$ of the total number of birds of prey in mixed groups while in the overall statistics Honey Buzzard is a subdominant species on migration making $15.33 \%$ of the total number of migrating birds of prey. From the number of migrating Honey Buzzards only $2.47 \%$ were found in mixed flocks.

The average number of individuals in mixed groups was $4.3 \pm 0.68$, which is slightly higher than in monospecies groups where the average number of birds was $3.66 \pm 0.65$. These differences are statisti- 
тювик европейский (Accipiter brevipes) 10 регистраций, могильник (Aquila heliaca) - 13, беркут (A. chrysaetos) - 7, степной oрёл (A. nipalensis) - 3, курганник (Buteo rufinus) - 11, змееям (Circaetus gallicus) 7, болотный мунь (Circus aeruginosus) - 35, полевой мунь (C. cyaneus) - 24, степной мунь (C. macrourus) - 10, луговой кунь (C. pygargus) - 17, орлан-белохвост (Haliaeetus albicilla) - 5, чёрный коршун (Milvus migrans) - 26, скопа (Pandion haliaetus) - 14, балобан (Falco cherrug) - 9, кречет (F. rusticolus) - 1 (возможно - птица, улетевшая из неволи), дербник (Falco columbarius) - 9, обыкновенная пустельга (F. tinnunculus) - 20, кобчик (F. vespertinus) - 11 регистраций (см. рис. 2).

Следует отметить, что не всегла была возможность четко отАелить местных перепелятников от мигрируюших, поэтому к мигрантам относили только "явных" транзитных, летевших на большой высоте в определенном - характерном мия данно-

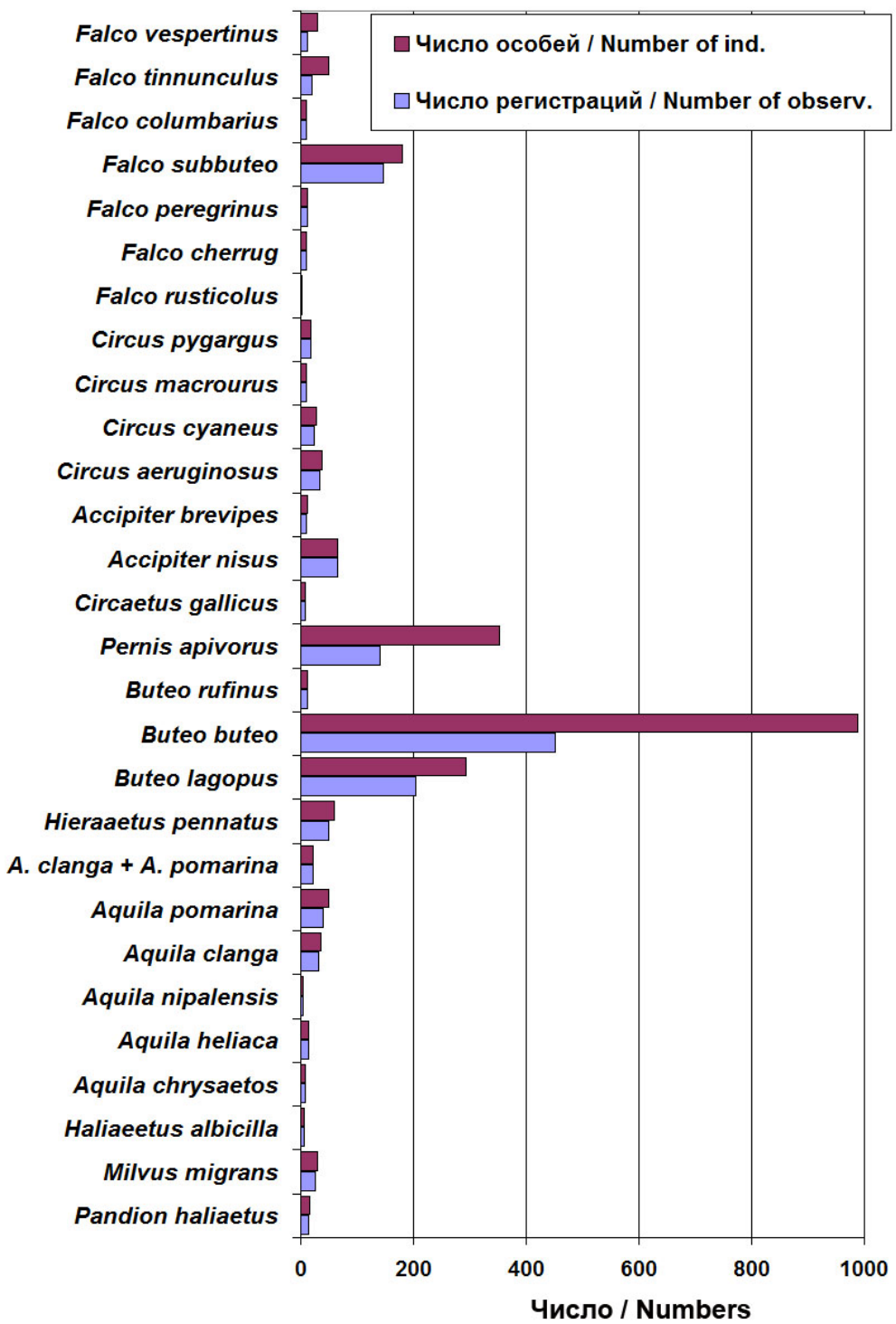

cally unreliable. The biggest flock consisted of 25 birds for a mixed group and 31 birds for monospecies group, however, the biggest mixed group without non-raptor species had only 10 birds. The most common size of the mixed group was 3 individuals $44.1 \%$ of a number of mixed groups; mixed groups of 2 individuals were observed in $23.5 \%$ of cases. On the other hand, the most common size for a monospecies group was 2 raptors - $53.7 \%$ of all monospecies groups and groups of 3 individuals make only $20.6 \%$.

\section{Status of the migrant birds of prey - transit, migration stopovers, nomadic}

For the most species (18 out of 17 , or $66.6 \%)$ transit individuals prevail over those who make a stopover during migration (fig. 4). For instance, 2/3 of all Common Buzzards and Booted Eagles, $90 \%$ of Honey Buzzards, $60 \%$ of Golden Eagles, $60 \%$ of Eurasian Hobbies, $60 \%$ of Levant Sparrowhawks, $70 \%$ of Common Kestrels, $70 \%$ of Eastern Imperial Eagles and $65 \%$ of Lesser Spotted Eagles were transit. The number of transit and making a stopover Hen and Pallid Harriers in this region was equal. For 7 species (25.9\%) individuals on stopovers prevail over transit ones. These 7 species are Steppe Eagle (100\%), Shorttoed Eagle (80\%), Greater Spotted Eagle (60\%), Osprey (77\%), Merlin (75\%), Peregrine Falcon (60\%), Red-footed Falcon (80 $\%)$ (fig. 4). Nomadic behavior was noted in Steppe Eagle, Rough-legged Buzzard, and Gyrfalcon. Fig. 4 and 5 show status dispersion of migrating birds of prey. Notable that Greater Spotted Eagle in the Kharkov region is a species observed mostly on migration stopovers while in other regions like Western Siberia or Kazakhstan this species demonstrates a strategy of long-term migratory jerks surpassing very big distances in the shortest terms. For example, I. Karyakin describes Greater Spotted Eagles who flew $1,876 \mathrm{~km}$ in 6 days and $898 \mathrm{~km}$ in 2 days (Karyakin, 2016). At the same time, in the group of not identified Spotted Eagles transit birds are in majority (76\%). Even if they all are Greater Spotted Eagles - this

Рис. 2. Соотношения количества регистраций и особей мигрируюших хишных птиц разных видов.

Fig. 2. A ratio between number of registrations and number of migrating individuals for species under study. 
го сезона - направлении. Болотных луней, орланов-белохвостов и чёрных коршунов, равно как и пустельг в агроландшастах, также Аостаточно сложно было разделять на мигрируюших (останавливаюшихся на миграции) и местных: особенности окраски этих видов Аалеко не всегАа позволяет проводить индивидуаиьное распознавание, а характер миграционного перемещения болотных муней может не иметь сушественных отличий от охотничьих перемешений местных особей. Таким образом, мы приводим минимальные оценки численности мигрируюших чёрных коршунов, орланов-белохвостов, обыкновенных пустельг, перепелятников и болотных луней, и эти оценки, скорее всего, сушественно занижены. Это же, возможно, вносит некоторое искажение в соотношение особей по статусу пребывания мля этих виАов (см. ниже).

Анализ всей совокупности учтённых особей даёт следуюшие результаты: среди 2368 отмеченных нами особей наибольшее количество - 989 (41,7 \%) приходится на обыкновенного канюка, что заметно превышает Аолю этого вида в выборке по регистрациям. Это, как и большую Аолю осоела и зимняка, можно объяснить такой характерной чертой миграционной биомогии вида, как перемешения в группах. Вторым по численности особей является осоен (в выборке по регистрациям - зимняк) - 363 особи (15,33 \%). К субдоминантам, помимо осоеда, можно отнести зимняка (294 особи, 12,42 \%) и чеглока (180 особей, ими 7,60 \%). К обычным видам можно отнести орла-карлика и перепелятника, а также мамого подорлика и обыкновенную пустельгу (см. табл. 1).

\section{2. Численность мигрирующих групп, их виАовой СОстав}

Аия всех видов соколообразных и ястребообразных в районе исследования наиболее характерным является перемешение в одиночку, гораздо реже - небольшими группами и цостаточно редко - стаями (см. табл. 2). Такая картина разительным образом отличается от наблюАаемой в "бутылочных горлышках" миграционных коридоров - нац Гибрамтаром, в Батуми (Грузия), Чумпхоне (Таиланд) (Allen, DeCandido, 2007; Birding Cadiz Province, 2017; BRC, 2017).

Из 27 видов Аля 9 (т.е. 1/3) отмечены перемешения искиючительно одиночек. Ешё мля 2 виАов - лугового и степного луней - отмечены перемешения одиночных assumption does not significantly decrease the proportion of stopover birds (fig. 5).

We compared the migratory strategy of Greater and Lesser Spotted Eagles. The differences between strategies of these species are statistically significant ( $p$-value = 0.0138, odds ratio: 6.1447): for Lesser Spotted Eagle the characteristic feature is moving both solitary and in pairs (in $70 \%$ of observations we were registered solitary birds). And Greater Spotted Eagle prefers to migrate solitary (see below).

We did not find correlations in the migration status of Greater and Lesser Spotted Eagles ( $p$-value $=0.0624$, odds ratio: 2.5173 ) (see below). Accumulation of more data is necessary to study the migration strategy preferences in these two species. We expect Greater Spotted Eagle to pass through the region or make stopovers in equal proportion, while Lesser Spotted Eagles we expect to pass the region mainly on transit.

\section{Migration phenology}

In this article, we provide key data on migrating of Birds of Prey through the study region.

Table 3 shows the distribution of migrating birds of prey by months. The highest intensity of migration was observed in September and October, and to a lesser extent - in March, April, and August. In February and November, migration is intensive as well. In June - July and December - January migration is about zero with only nomadic Roughlegged Buzzards registered in winter.

September - is a time of the main migration of both species of Spotted Eagles. Up to $60 \%$ of all registered Spotted Eagles pass the region in September. In spring, Lesser Spotted Eagles are mainly seen in April (about 4/5 from all spring registrations of the species). Greater Spotted Eagles pass through the region both in March and April. The latest observations of Greater Spotted Eagle were done in November and once in December on 11/12/2010 (probably wintering specimen). The latest observations of Lesser Spotted Eagles took place in second half of October (2022/10/2012) (table 4).

Golden Eagles were observed mainly in March and in September accumulating $60 \%$ of all species observations (30\% per month). December, November, February, and October accumulate the rest $40 \%$ of the species recordings (10\% per each month).

Steppe Eagles were registered three times: in April, July, and September. 
Табл. 1. Общее число особей мигрируюших хищных птиц.

Table 1. A total number of migrating raptor's individuals.

\begin{tabular}{|c|c|c|c|}
\hline $\begin{array}{l}\text { Bим } \\
\text { Species }\end{array}$ & $\begin{array}{l}\text { Численность } \\
\text { Number }\end{array}$ & $\begin{array}{l}\text { Аоля от общего } \\
\text { количества } \\
\text { мигрантов,\% } \\
\text { Share from total } \\
\text { number of mi- } \\
\text { grants, \% }\end{array}$ & $\begin{array}{l}\text { Примечание } \\
\text { Notation }\end{array}$ \\
\hline Pandion haliaetus & 16 & 0.68 & Редкий, численность растет / Rare, with growing numbers \\
\hline Milvus migrans* & 29 & 1.22 & Мамочисленный / Not numerous \\
\hline Haliaeetus albicilla* & 5 & 0.21 & РеАкий / Rare \\
\hline Aquila chrysaetos & 7 & 0.30 & Редкий, нерегулярно встречаюшийся / Rare, non-regular \\
\hline Aquila heliacal & 13 & 0.55 & Редкий / Rare \\
\hline Aquila nipalensis & 3 & 0.13 & Крайне реАкий, нерегулярно встречаюшийся / Extremely rare \\
\hline Aquila clanga & 36 & 1.52 & Мамочисленный / Not numerous \\
\hline Aquila pomarina & 50 & 2.11 & Обычный / Common \\
\hline $\begin{array}{l}\text { Aquila clanga }+ \\
\text { A. pomarina** }\end{array}$ & 22 & 0.93 & \\
\hline Hieraaetus pennatus & 60 & 2.53 & Обычный / Common \\
\hline Buteo lagopus & 294 & 12.42 & Субдоминант / Subdominant species \\
\hline Buteo buteo & 989 & 41.77 & Аоминант / Dominant species \\
\hline Buteo rufinus & 12 & 0.51 & РеАкий / Rare \\
\hline Pernis apivorus & 363 & 15.33 & Субдоминант / Subdominant species \\
\hline Circaetus gallicus & 7 & 0.30 & Редкий, нерегулярно встречаюшийся / Rare, non-regular \\
\hline Accipiter nisus* & 77 & 3.25 & Обычный / Common \\
\hline Accipiter brevipes & 12 & 0.51 & Редкий, нерегулярно встречаюшийся / Rare, non-regular \\
\hline Circus aeruginosus & 38 & 1.60 & Малочисленный / Not numerous \\
\hline Circus cyaneus & 28 & 1.18 & Малочисленный / Not numerous \\
\hline Circus macrourus & 10 & 0.42 & Редкий / Rare \\
\hline Circus pygargus $* * *$ & 17 & 0.72 & Редкий / Rare \\
\hline Falco rusticolus $* * *$ & 1 & 0.04 & Крайне редкий / Extremely rare \\
\hline Falco cherrug & 9 & 0.38 & Редкий, нерегулярно встречаюшийся / Rare, non-regular \\
\hline Falco peregrinus & 11 & 0.46 & Редкий / Rare \\
\hline Falco subbuteo & 180 & 7.60 & Субдоминант / Subdominant species \\
\hline Falco columbarius & 9 & 0.38 & Редкий / Rare \\
\hline Falco tinnunculus *** & 50 & 2.11 & Обычный / Common \\
\hline Falco vespertinus & 30 & 1.27 & $\begin{array}{l}\text { Малочисленный, численность растет / Not numerous with } \\
\text { growing numbers }\end{array}$ \\
\hline Bcero / Total & 2368 & 100 & \\
\hline
\end{tabular}

Примечание / Note:

* численность занижена в виду трудности идентисрикации местных особей и мигрантов (см. в тексте) / the number is underestimated because of the difficulties in identification of resident individuals and migrants (see in text);

** возможно, данная позиция вкиючает в себя в равной пропорции неопределенных до вида особей как большого, так и малого подорликов / this position probably includes undefined individuals of both Lesser and Greater Spotted Eagles in equal proportions

*** нет выраженного тяготения к речным долинам, в период миграции более характерны на водоразделах, гле наблюдения проводили эпизодически; данные о численности в период миграции занижены / no pronounced attraction to the river valleys, during migration are common in the watersheds where the surveillance was carried out sporadically; the number of migrating individuals is underestimated;

**** регистрация этого вида вызывает определённые сомнения у некоторых комег, мы же уверены в правильности определения птицы, однако данная встреча, возможно, связана с отлетом особи из неволи / registration of this species raises certain doubts in our colleagues. However, we are confident in the correct field identification of the bird, but it could be an individual escaped from captivity. 
Табл. 2. Распределение регистраций мигрируюших хищных птиц между группами по чисиу особей в мигрируюшей группе.

Table 2. Registrations of migrating birds of prey distributed by number of individuals in a group.

\begin{tabular}{|c|c|c|c|c|c|c|c|c|c|c|c|c|c|c|c|c|c|c|c|c|c|}
\hline \multirow{2}{*}{$\begin{array}{l}\text { Вих } \\
\text { Species }\end{array}$} & \multicolumn{21}{|c|}{ Число особей в группе / Number of individuals in a group } \\
\hline & 1 & $\mathbf{2}$ & 3 & 4 & 5 & 6 & 7 & 8 & 9 & 10 & 11 & 12 & 13 & 14 & 15 & 16 & 17 & 18 & 29 & 30 & 31 \\
\hline $\begin{array}{l}\text { Aquila clanga }+ \\
\text { A. pomarina }\end{array}$ & 20 & 1 & & & & & & & & & & & & & & & & & & & \\
\hline Accipiter brevipes & 8 & 2 & & & & & & & & & & & & & & & & & & & \\
\hline Accipiter nisus & 61 & 2 & 1 & & & & & & 1 & & & & & & & & & & & & \\
\hline Aquila chrysaetos & 7 & & & & & & & & & & & & & & & & & & & & \\
\hline Aquila clanga & 32 & 2 & & & & & & & & & & & & & & & & & & & \\
\hline Aquila heliaca & 13 & & & & & & & & & & & & & & & & & & & & \\
\hline Aquila nipalensis & 3 & & & & & & & & & & & & & & & & & & & & \\
\hline Aquila pomarina & 28 & 11 & & & & & & & & & & & & & & & & & & & \\
\hline Buteo buteo & 277 & 78 & 36 & 14 & 15 & 7 & 5 & 2 & 4 & 1 & 1 & 2 & 1 & 2 & 2 & 2 & 1 & 1 & & & \\
\hline Buteo lagopus & 15 & 27 & 2 & 2 & 2 & 2 & & & & & & & & & & & & & & & \\
\hline Buteo rufinus & 1 & 1 & & & & & & & & & & & & & & & & & & & \\
\hline Circaetus gallicus & 7 & & & & & & & & & & & & & & & & & & & & \\
\hline Circus aeruginosus & 31 & 2 & 1 & & & & & & & & & & & & & & & & & & \\
\hline Circus cyaneus & 2 & 4 & & & & & & & & & & & & & & & & & & & \\
\hline Circus macrourus & 1 & & & & & & & & & & & & & & & & & & & & \\
\hline Circus pygargus & 17 & & & & & & & & & & & & & & & & & & & & \\
\hline Falco cherrug & 9 & & & & & & & & & & & & & & & & & & & & \\
\hline Falco columbarius & 9 & & & & & & & & & & & & & & & & & & & & \\
\hline Falco peregrinus & 11 & & & & & & & & & & & & & & & & & & & & \\
\hline Falco rusticolus & 1 & & & & & & & & & & & & & & & & & & & & \\
\hline Falco subbuteo & 123 & 2 & 1 & 2 & & 1 & & & & & & & & & & & & & & & \\
\hline Falco tinnunculus & 17 & 2 & & & & & & & & & & & & & & & & & 1 & & \\
\hline Falco vespertinus & 5 & 2 & 2 & & & 1 & & & 1 & & & & & & & & & & & & \\
\hline Haliaeetus albicilla & 5 & & & & & & & & & & & & & & & & & & & & \\
\hline $\begin{array}{l}\text { Hieraaetus penna- } \\
\text { tus }\end{array}$ & 43 & 7 & 1 & & & & & & & & & & & & & & & & & & \\
\hline Milvus migrans & 24 & 1 & 1 & & & & & & & & & & & & & & & & & & \\
\hline Pandion haliaetus & 12 & 2 & & & & & & & & & & & & & & & & & & & \\
\hline Pernis apivorus & 8 & 29 & 11 & 5 & 4 & 3 & 2 & 1 & 1 & & & & 1 & & & & & & 1 & 1 & 1 \\
\hline
\end{tabular}

птиц во время транзитных перелетов, оАнако эти виды охотно образуют группы от 2-3 до 7 особей в местах ночёвок. Среди орлов фрактически мия всех видов характерно перемешение в одиночку, только мля орла-карлика этот показатель оценен в 84,3 \% регистраций, а мамый подорлик может быть назван единственным видом настояших орлов, мия миграционных перемешений которого Аостаточно характерны мигрирующие пары (регистрации: 27,5 \% - в парах, 2,5 \% - группа из 4 птиц, 70,0 \% - регистрации одиночных птиц) (рис. 3). Уникальным мия региона было наблюдение группы мигрируюших подорликов, состояшей из 2 больших и 4 малых подорликов; это явление отмечено накануне значительного ухудшения погодных условий. Аяя могильника и беркута, равно как мия змееяла и орлана-белохвоста вообше не отмечены миграционные перемешения в
The most of Eastern Imperial Eagles registrations were done in September.

Booted Eagles were seen on autumn migration mainly in September - $75 \%$.

Autumn migration of Common Buzzard is well-studied. About $55 \%$ of all migrant Common Buzzards registrations were done in September and $25 \%$ - in October. August, March, and April cover no more than $5 \%$ of Common Buzzard registrations each

The distribution of migrant Rough-Legged Buzzards is rather uniform between October (25\%), March (25\%), February (20\%) and December (15\%).

Autumn migration of Long-Legged Buzzard is also evenly distributed between $\mathrm{Au}$ gust (30\%), September (30\%) and October (33\%). Spring registrations of this species are very rare (only March).

Short-Toed Eagles were registered in September (70\% of all observations of this 
группах, парах. Скопы летят, в основном, в одиночку, хотя $\Delta$ о $14,3 \%$ регистраций все же приходится на пары (табл. 2).

Одиночные мигранты преобладами и в наблюдениях таких видов, мия которых характерно перемешение в группах, например, обыкновенный канюк и осоеА (см. табл. 2). Аия канюка 61,4\% регистраций приходится на одиночных мигрантов, $17,3 \%$ - на мигрантов в парах, и по $8 \%$, 3,1 \% и 3,3 \% приходится на группы по 3, 4 и 5 канюков соответственно. Наиболее крупные стаи насчитывают 14, 17 и 23 особи, отмечены в 3 мекале сентября и в средних числах октября, как правило - в период прояснений, приходящих на смену большому цикиону. Аия осоела более помовины регистраций мигрантов в условиях Восточно-Европейской равнины прихоАИтся на одиночных птиц - 57,1 \%, пары отмечены в 20,7 \% регистраций, группы из трех птиц - в $7.8 \%$, а из 4 - только в $3,57 \%$ регистраций. Максимамьные по размерам стаи - 29, 30 и 31 особь отмечены 26.08.2016 в пик миграции вида, в условиях прояснения после затянувшихся обложных АожАей.

Следовательно, формирование крупных стай мигрируюшими канюками и осоелами не является характерной чертой миграционной стратегии этих видов в условиях умеренных широт степных и лесостепных равнинных ландшасртов. И в таких условиях на осеннем пролете стаи могут формироваться при стечении некоторых обстоятельств, как-то: резкая смена погоды (окончание осадков, резкое похолодание) или, наоборот, “беспросветность" в погоде - продолжительные осадки, формирование особо благоприятной кормовой базы на убранных полях (концентрация птиц, останавливаюшихся на миграции в Аанном регионе).

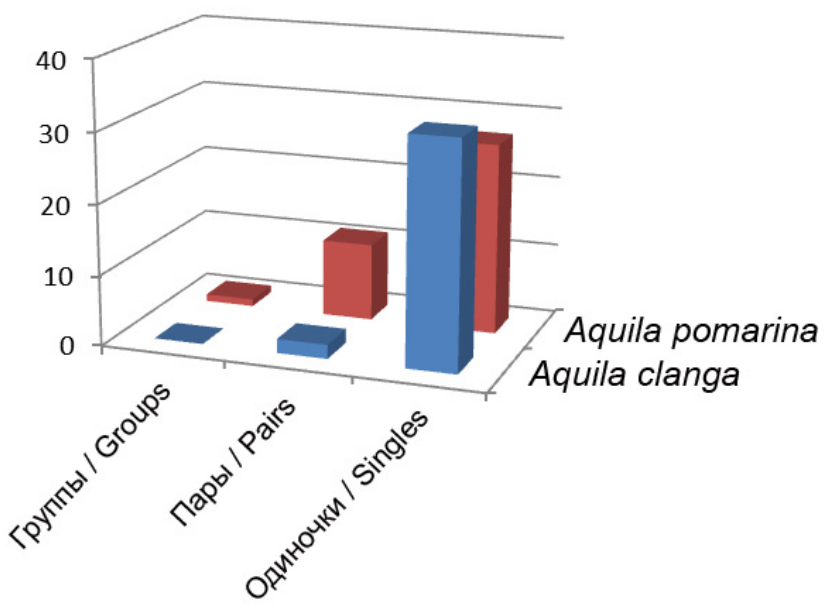

species), and rarely in August (15\%) and May (15\%).

Honey Buzzards were observed in September (55 \%) and August (35\%). An insignificant number passed in October and in spring.

Black Kites were seen in April, August, and September. The distribution of migrating individuals between these months is even.

White-Tailed Eagles' intense migration was seen in March and October - $40 \%$ per month, less often - in November - $20 \%$.

Hen Harriers in Autumn were mostly seen in October - 4/5 from all registrations of the species. In Spring migrations took place mainly in February and March.

Pallid Harriers in Autumn were evenly distributed between August and September, and in Spring were seen only in April.

Marsh Harriers' autumn registrations took place in September - mainly in $1^{\text {st }}$ and $2^{\text {nd }}$ decades of the month when more than $2 / 3$ of all Marsh Harriers were observed.

Montagu's Harriers can be seen in September (60\% of all autumn registrations) and in August (30\%).

Hawks' migration is well pronounced in autumn: Levant Sparrowhawks pass mainly in August (40\%) and September (another $40 \%)$, and less often in early October (20\%). Eurasian Sparrowhawks migrate mainly in September (60\%) and in October (35\%).

Falcons autumn migration is most prominent in September and October. The September-prevail species are Common Kestrel (70\% in September, $15 \%$ in August and $10 \%$ in October), Eurasian Hobby (80\% in September, $10 \%$ in October and $7 \%$ in August), Red-footed Falcon (70 \% in September, $20 \%$ in August and $10 \%$ in May), and Saker (60\% in September, $20 \%$ in October, $10 \%$ in March and $10 \%$ in April). The October-prevail species are Merlin (70 \% in October and $10 \%$ each in November, September, and April) and Peregrine (45\% in October, $20 \%$ in August, $20 \%$ in September and $15 \%$ in spring months).

From 2012 to 2016 we observed a shift in terms of start and peak of autumn migration to earlier dates in some species. For instance, in Honey Buzzards migration maximum shifted from $1^{\text {st }}$ and $2^{\text {nd }}$ decades

Рис. 3. Число особей малого (Aquila pomarina) и большого (A. clanga) подорликов, перемешаюшихся в одиночку, парами ими в группах.

Fig. 3. A number of individuals of Lesser and Greater Spotted Eagles (Aquila pomarina, A. clanga) migrating alone, in pairs or in groups. 
Помимо миграций в одиночку, парами, группами и стаями, состояшими из преАставителей одного вида, интересной чертой хишных птиц семейства Accipitridae является формирование смешанных стай, состояших из преАставителей нескольких видов. Всего отмечено 73 таких регистрации, что составляет 5,24 \% от обшей суммы регистраций мигрируюших хишных птиц $(n=1389)$. Если брать в расчет обшее количество особей, учтённых в таких регистрациях, то из 2368 особей мигрирующих хищных птиц 123 или 5,2 \% учтены в смешанных группах. Всего 15 видов из 27 (т.е. 55,5 \%) участвуют в образовании смешанных групп, также отмечено участие трёх видов "нехишных" птиц: 24 ворона (Corvus corax) образовываяи группу с 1 обыкновенным канюком, 1 чёрный аист (Ciconia nigra) - с обыкновенным канюком, 1 серый журавль (Grus grus) - с 1 обыкновенным канюком и подорликом, не определенным до вида (скорее всего - большим).

Наиболее скионными к участию в образовании смешанных групп мигрантов можно назвать мамого подорлика - около 20 \% всех отмеченных малых подорликов перемешалось в смешанных стаях, состояших из преАставителей Авух и более видов. При этом доля малого подорлика от обшего числа хишных птиц в смешанных стаях составила 8,04\%.

Наиболее многочисленный вид в смешанных стаях был обыкновенный канюк. На его Аолю приходится почти половина особей в смешанных группах - 58 из 123 , или 47,15 \%. Этот показатель мишь немного отличается от Аоли вила в обшей выборке мигрантов (см. выше). В то же время, в смешанных стаях отмечено кишь 5,9\% всех мигрируюших канюков, абсолютное же большинство регистраций канюка приходится на моновидовые скопления. Следовательно, этот вид следует признать не скионным к образованию смешанных групп / стай с Аругими вилами. Практически в $100 \%$ случаев вовлечение канюков в смешанные группы происходило путём присоединения особей или пар Аругих виАов к группам канюков.

Осоеды составляют 7,32 \% от численности хишных птиц в смешанных группах, в то время как в обшей выборке этот виА выступает в роли субдоминанта с Аолей в $15,33 \%$. Из обшего числа мигрируюших осоедов, Аишь 2,47 \% летят в смешанных группах.

Среднее число особей в смешанных

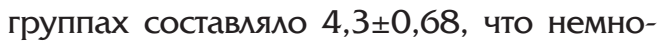

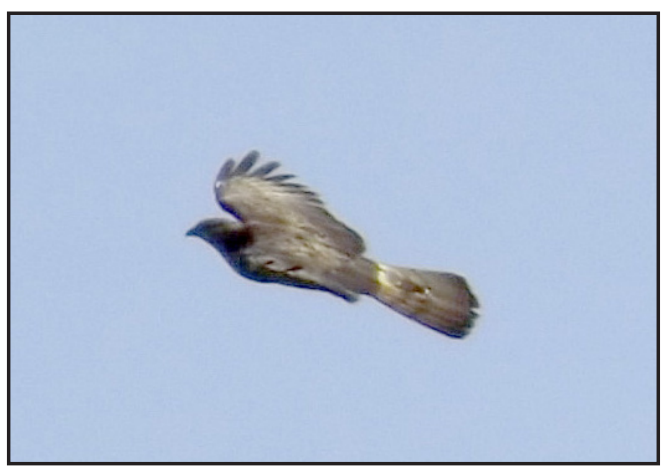

Ocoе^ (Pernis apivorus). Фото И. Козицкого.

Honey Buzzard (Pernis apivorus). Photo by I. Kozitsky.

of September to the second half of August and the very first migrants today can be seen as early as in August 1-10 compared with August 18-20 in 2012; in Black Kites and Hobbies the beginning of autumn migration in the study area shifted from the first days of September to the middle of August, in Common Buzzard - from September 5-7 to August 10-20. We also observed increasing number of Red-footed Falcons and Pallid Harriers in August and decreasing of this species amount among September migrants.

We compared the terms of raptors migrations observed today (2005-2016) with data concerning $19^{\text {th }}$ century published by N.N. Somov (1897). This author noted indefinite autumn migration of Black Kite - birds moved non-intensively, mostly singled and less often in pairs or in family groups; the migration peak was described in the $3^{\text {rd }}$ decade of August and in the first half of September (beginning of spring migration in early April, ending of autumn migration in late September - early October). Today the situation is the same. In Sparrowhawks undefined spring migration more resembled brief nomadic movements in March was noted in 1800-s. Autumn migration was pronounced throughout September with a peak in the beginning - midSeptember. Our observations showed an identical situation. Migrating Saker Falcons were recorded in the $2^{\text {nd }}-3$ rd decades of September both in the $19^{\text {th }}$ century and in the $21^{\text {st }}$ century. The peak of Osprey's migration was noted at the end of March early April in the $19^{\text {th }}$ century, and in the $21^{\text {st }}$ century - from the beginning to the middle of April; the terms of autumn migration has not changed. For White-Tailed Eagle N.N. Somov noted a very intense autumn migration. On 01/11/1879 (19/10/1879 in the old style) he counted about 40 birds in 
го выше, нежели в моновидовых группах

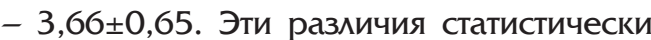
недостоверны. Экстремамьные значения составили, соответственно, 25 и 31 особь, однако в смешанных группах без участия "нехишных" птиц наиболее крупная смешанная группа состояла из 10 особей. Интересно, что наиболее часто встречаюшейся величиной смешанной группы было 3 особи (44,1 \% от всех смешанных групп), а группы из 2 особей встречались гораздо реже $(23,5 \%)$, в то время, как м^я моновиАовых групп наиболее часто встречались "Авойки" - 53,7 \% от всех моновидовых групп (на группы из 3 особей приходилось 20,6 \%). Следует отметить, что из 34 групп в 4 группах $(11,7 \%)$ отмечены консликтные ситуации: 2 - при участии мелких соколов (пустельга, чеглок) и птиц-парителей (обыкновенный канюк, могильник), а также межАу степным лунем и обыкновенным канюком, канюком и мамым подорликом. Возможно, что в этом случае само формирование группы птиц было вызвано именно возникновением консликтной ситуации межАу охотившимися птицами. ИскАючение составляет консрликтная ситуация между малым подорликом и одним из обыкновенных канюков, когАа после непродолжительных атак все три птицы (2 канюка и 1 подорлик) мирно продолжили миграционное перемешение.

\section{3. Статус мигрирующих птиц - тран-} зитные, остановки на миграции, кочевки

Ая большинства видов отмечено преобмахание транзитных мигрируюших особей наА останавливаюшимися на миграции: таких 18 видов из 27, или 66,6 \% (см. рис. 4). Например, около 2/3 из учтенных канюков и орлов-карликов, 90 \% осоелов, 60 \% беркутов, тювиков и чеглоков, 70 \% обыкновенных пустельг и могильников и 65 \% мамых подорликов могут быть отнесены к транзитным мигрантам. Аия 2 видов (полевой и степной муни) отмечены паритетные соотношения основных статусов. Аия 7 видов $(25,9 \%)$ - степной орёл (100\%), змееял (80\%), дербник (75 \%), сапсан (60\%), кобчик (80\%), большой подорлик (60\%), скопа (77 \%) - отмечено преоблацание особей, останавливаюшихся на миграции нах транзитными (рис. 4). Кочевки отмечены мля зимняка, кречета и степного орла. На рис. 4-5 показаны распределения статусов мигрируюших хишных птиц. Интересно отметить, что в условиях Харьковской области большая часть мигрируюших боль- one hour (Somov, 1897); at the present, we didn't note a pronounced migration of White-Tailed Eagles, only nomadic movements during November-December and in February. We found no differences in the terms of spring and autumn migrations of Eurasian and Levant Sparrowhawks, Hobby, Short-Toed Eagle and Greater Spotted Eagle. Migrant Peregrines were observed in the $19^{\text {th }}$ century in autumn during September - early October, and in the $21^{\text {st }}$ century - from the end of August to the middle of November. Thus, the extension of the autumn migration of Peregrine has occurred. Merlin's migration in the 19 century was noted during the whole September (Somov, 1897), and in present, its migration occurs in remarkably later terms - from the end of September to beginning of November.

\section{Direction and altitude of transit mi- grations \\ Autumn}

The main directions of the autumn migrations are south, southeast, and south-eastsouth; less often are west, southwest and other directions between east, south, and west (fig.6).

The southern direction is popular among Common Buzzards (60\% of all individuals of this species), Honey Buzzards (50\%), Ospreys (100\%), Lesser Spotted Eagles (50 \%), Booted Eagles (45 \%), Black Kites (25\%), Montagu's Harriers (45\%), Hen Harriers (40\%), Levant Sparrowhawks (60\%), Eurasian Sparrowhawks (50 \%), Common Kestrels (67\%) and Hobbies (60\%).

The south-east-south is the main direction for Pallid Harriers (about $100 \%$ ), March Harriers (70\%), Hen Harriers (40\%), and Longlegged Buzzards (40\%).

The south-east direction is popular among Short-toed Eagles (100 \%), Greater Spotted Eagles (45 \%), Lesser Spotted (30\%) and Booted Eagles (30\%), Long-Legged Buzzards (40\%), as well as for Eurasian (20\%) and Levant Sparrowhawks (20\%).

The west is the main direction for Red-Footed Falcons (about $50 \%$ ) and Pallid Harriers (25\%). Southwest is the main direction for Merlin (50 \%), Levant Sparrowhawk (20\%), Black Kite (45 \%) and Golden Eagle (100\%).

\section{Spring migrations}

According to our observations, the main direction for migrating raptors in spring is northeast: $50 \%$ of Montagu's Harriers, $67 \%$ of Hen Harriers, $50 \%$ of White-Tailed Eagles, $40 \%$ of Common Buzzards and $40 \%$ of Spot- 


\section{Доля от общего числа наблюдений Share of total number of observations}

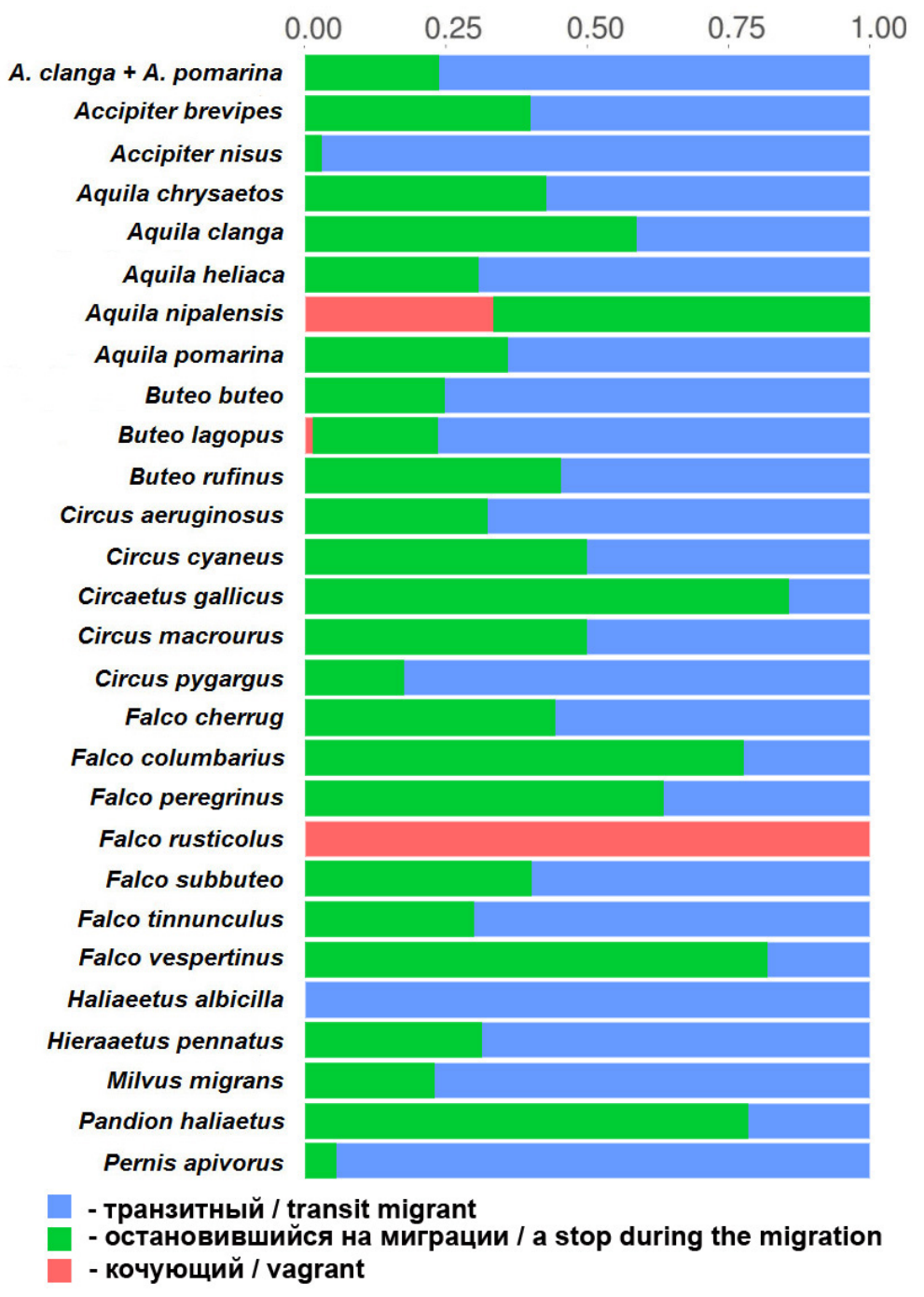

ших подорликов отнесена к группе останавливаюшихся на миграции, в то время как в Аругих регионах (Запацная Сибирь, Казахстан) этот вид демонстрирует стратегию Аальних миграционных рывков, преоАолевая значительные расстояния за кратчайшие сроки, например, Ао 1876 км за 6 дней и 898 км за 2 дня (Карякин, 2016). ОАновременно в группе подорликов, не определенных $\Delta$ вида, преобладают транзитные мигранты (таких 76 \%). Возможно, что большая часть этих птиц относится к виду большого подорлика, что, однако, все же сушественно не умачяет Аоли птиц, останавливаюшихся на миграции (рис. 5).

В случае некоторых видов (перепелятник, орлан-белохвост, болотный мунь, в меньшей степени - обыкновенная пустельга и черный коршун) было тяжело отличить местных птиц от останавливаюшихся на миграции, поэтому имеет место завы-
Рис. 4. Статус мигрируюших хишных птиц, Харьковская область Украины.

Fig. 4. Migration status of birds of prey in Kharkiv region (Ukraine).

ted Eagles (both Greater and Lesser) are going in this direction. This direction is unique for Ospreys, Merlins, Sakers, Pallid Harriers and Eurasian Sparrowhawks - $100 \%$ of this species are going in this direction in spring. The north direction is popular among Honey Buzzards (50\%), White-Tailed Eagles (50\%), Common Buzzards (40\%), Lesser (40\%) and Greater Spotted Eagles (40\%), Hen Harriers (50 \%) and Black Kites (50\%), and is unique for Common Kestrels (100\%), Peregrines (100\%), March Harriers (100\%) and Long-Legged Buzzards (100\%).

The north-west direction is popular for Rough-Legged Buzzards (50\% of all registrations of this species).

More details about the direction of raptor's migration can be seen in table 5 .

\section{Altitudinal distribution of migratory raptors}

On the fig. 7 and 8 the altitudinal distribution of different raptor species observed in our work is presented. Generally, the mean altitudes of autumn migrations are lower than in the spring. It can be explained by the fact that spring migration goes faster since birds of prey looking forward to occupying their breeding sites on the north and passing through our research area in transit at high altitude (fig. 8).

Distribution by species:

Lesser Spotted Eagles on spring migration stay at 100-200 m height, while in autumn their fly altitude is more evenly distributed (fig. 8). Greater Spotted Eagles on spring migration have even narrower altitudinal range - 350-400 $\mathrm{m}$ and flying much higher than Lesser Spotted Eagles. On autumn migration their altitude distribution is identical to Lesser Spotted Eagles (fig. 8).

White-Tailed Eagle is characterized by the highest migration altitudes: the minimal height was higher than $150 \mathrm{~m}$.

Ospreys in spring use all altitude ranges, and in Autumn they prefer altitudes below $150 \mathrm{~m}$.

Hen Harriers fly lower in spring (below $200 \mathrm{~m}$ ) than in autumn (evenly distributed altitudes). Marsh Harriers are evenly distributed between all altitude ranges during spring migration and prefer low altitudes below $100 \mathrm{~m}$ in autumn (fig. 8). 


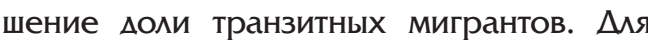
обыкновенной пустельги, миграции которой, похоже, не приурочены к миграционным коридорам и часто имеют вид медменных перемешений на небольшой высоте, Аанные численности мигрантов как останавливаюшихся, так и транзитных явно занижены. Также мия этого вида вряд ми возможно получить корректные показатели соотношения транзитных и останавмиваюшихся на миграции особей.

Прогнозированием ситуации при изменении выборки установлено, что мля большинства видов будет происходить выравнивание распределения между группой транзитных особей и останавливаюшимися на миграционных перемешениях, равно как и кочуюших. При увеличении выборки будет происходить выравнивание между количеством транзитных и останавмиваюшихся на миграции обыкновенных канюков и зимняков, все прогрессируюшее возрастание Аоли кочуюших зимняков в совокупности регистраций этого вида, сохранение преобладания транзитных чеглоков и осоедов нац останавливаюшимися на миграции особями этих видов (на соне увеличения Аоли кочуюших чеглоков). Что особенно интересно, ожидается сохранение преобладания Аоли останавливаюшихся на миграции больших подорликов нах транзитными. Сохранится также и преоблацание транзитных перепелятников нах останавливаюшимися на миграции.

Нами проведено сравнение стратегии миграции большого и малого подорликов. Различия между стратегиями видов значи-

\section{- остановившийся на миграции / a stop during the migration}

- транзитный / transit migrant

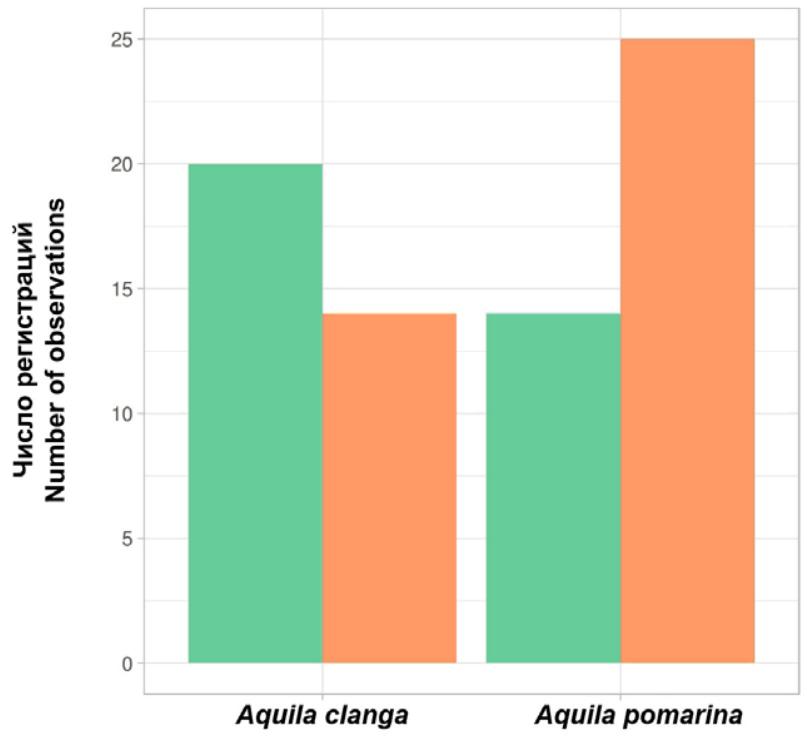

Red-Footed, Peregrine and Saker Falcons, Merlin, Montagu's, Pallid and Hen Harriers, Short-Toed Eagle, Long-Legged Buzzard, Booted Eagle and Levant and Eurasian Sparrowhawks migrate mainly on middle and low altitudes - below 200 m. Eagles (Aquila), Honey Buzzards and Common Kestrels are evenly distributed between all altitude ranges (fig. 7).

Common Buzzards prefer altitudes below $400 \mathrm{~m}$ and rarely use altitudes above 600 $m$ (mainly in October by transit groups). Rough-Legged Buzzards use low and middle altitudes (up to $200 \mathrm{~m}$ ) and hardly ever altitudes above $400 \mathrm{~m}$ (fig.7).

\section{Habitat distribution of migratory birds of prey}

We examined the biotopical distribution of hunting and resting birds on stopovers during migrations. The most important habitat is an open landscape of big river valleys (esp. Siversky Donets and Oskil rivers). It followed by a mosaic of open and wooded floodplains; floodplains of small rivers near the edges of upland oak forests and meadows; fields and wooded floodplains near villages; and fields and other agrarian landscapes (see Annex $2^{9}$ ).

The most important types of biotopes are open and forested landscapes of vast river floodplains, fields and meadows with steppe areas, and combinations of forests edge with open landscapes. Big lakes, water reservoirs, and big riverbeds are preferable biotopes for Osprey on migration stopovers. Open and forested (esp. edges) floodplains of big rivers attracted Levant Sparrowhawks (as least $50 \%$ of all registration of this species), Pallid Harriers (50 \% at least), Hen Harriers (40\%), Booted Eagles (33\%), most of Short-Toed Eagles passing through the region (another important habitat for this species - clearances in pine forests and old sparse grown pine forest), all Eurasian Sparrowhawks making migration stopovers, most of Eastern Imperial Eagles, Golden Eagles (67\%), and more than $50 \%$ of Merlins (other important habitats for Merlin are meadows in the valleys of small rivers and settlements). In total, at least half of all raptors were observed in the floodplains of big rivers.

Рис. 5. Число регистраций мачого и большого поАорликов - транзитных и останавливающихся на миграции.

Fig. 5. A number of registrations of the transit individuals and individuals on stopovers of the Lesser and Greater Spotted Eagles. 
мы (p-value=0,0138, odds ratio: 6,1447): мля малого подорлика характерной чертой миграционного перемешения является перемешение как пар, так и одиночных птиц (хотя одиночки отмечены чаше - приблизительно в $70 \%$ наблюдений), а мия большого подорлика характерной чертой миграционной стратегии является перемешение одиночных птиц (94,1%) (см. ниже).

Анаииз соотношения статусов пребывания большого и малого подорлика (транзитных и останавливаюшихся на миграциях птиц) не выявил значимой корреляции (p-value $=0,0624$, odds ratio: 2,5173) (см. ниже). Теоретически, при накоплении большего объема Аанных, можно было бы констатировать, что большие подорлики в равной мере преодолевают регион транзитом или останавливаются на миграции; мля мамых же подорликов более характерным было бы сушественное преоблахание транзитных миграций нах остановками.

\section{4. Фенология миграций}

Фенологические исследования представляют собой огромный, самостоятельный пласт исследовательской работы, вкиючают многочисленные виды анамиза связей наблюдаемых явлений в жизни живого организма с процессами, происходяшими в абиотической среде. Аанная статья не имеет целью проведение цетального анализа фенологических явлений и факторов, влияюших на них. Это тема отдельного, самостоятельного исследования. Мы ограничимся кишь приведением обших Аанных относительно киючевых Аат в миграциях хишных птиц.

В табл. 3 отображено распределение регистраций мигрируюших хишных птиц по месяцам. Наиболее интенсивно идет миграция в сентябре и октябре, в меньшей степени - марте, апреле и августе. $\Delta$ oстаточно выражена миграция и в ноябре, феврале. Фактически нет миграционных перемешений в июне - июле, а также в декабре - январе. В последнем случае отмечены кочевки зимняков.

В сентябре происходит миграция основной массы подорликов - $о 060$ м малых и больших подорликов. Весенние регистрации малых подорликов приходятся, в основном, на апрель: около 4/5 все регистраций вида. Большие подорлики в равной мере мигрируют в течение как марта, так и апреля. Есть регистрации мигрируюшего большого подорлика в ноябре и даже декабре (11.12.2010), в то время как са-

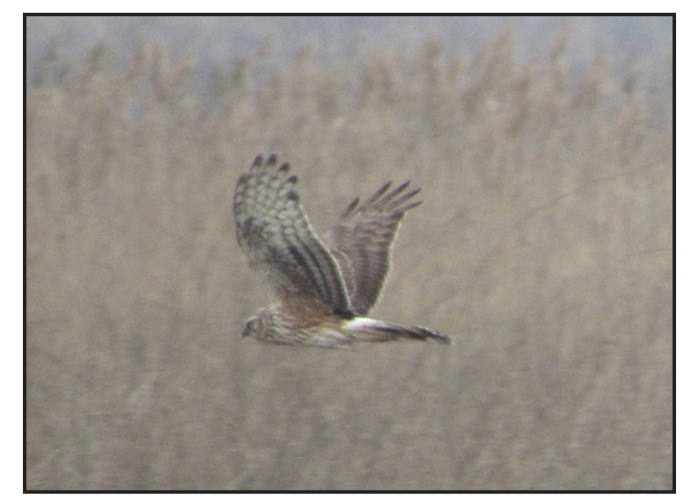

Полевой ^унь (Circus cyaneus). Фото С. Витера. Hen Harrier (Circus cyaneus). Photo by S. Viter.

Fields with inclusions of steppes and meadows is another important biotope. Fields attracted about $40 \%$ of Booted Eagles observed on migration stopovers, more than $40 \%$ of Hen, Pallid and Montagu's Harriers, about 1/3 from observed Common, Honey and Rough-Legged Buzzards and about $50 \%$ of Long-Legged Buzzards.

Table 6 represents the comparison of the importance of different biotopes for the most common migrants and 4 species of Eagles.

We found that the number of habitats which raptors used during spring migration is generally lower than in autumn. It is true for all species we analyzed (Booted Eagle, Lesser and Greater Spotted Eagles, Common Buzzard, Rough-Legged Buzzard, Honey Buzzard, Hen Harrier, Montagu's and Pallid Harriers).

More than $70 \%$ of migrating Birds of Prey were registered in ecotones of main habitats, namely:

- combination of open and wood covered floodplains;

- combination of upland oak forests, floodplains of small rivers with open landscapes (steppes, meadows, fields);

- combination of open floodplains with pine and alder forests.

Thus, floodplains of big rivers and river terraces with pine forests as well as edges of highland oak forests (especially if there is a small river nearby) turned out to be vitally important for migrating birds of prey.

\section{Habitat preferences by species}

For Booted Eagles the most important habitats during migration are open floodplains with meadows; ecotones between alder forests, meadows and oak or sparse grown forests; less important - ecotones of wooded and open floodplains. In spring Booted Eagles prefer upland oak forests, 
Табл. 3. Распределение мигрируюших хишных птиц по месяцам.

Table 3. Distribution of birds of prey registrations by months.

\begin{tabular}{|c|c|c|c|c|c|c|c|c|c|c|c|c|}
\hline \multirow{2}{*}{$\begin{array}{l}\text { Вим } \\
\text { Species }\end{array}$} & \multicolumn{11}{|c|}{ Месяц / Month } & \multirow{2}{*}{$\begin{array}{r}\text { Bcero } \\
\text { Total }\end{array}$} \\
\hline & 1 & 2 & 3 & 4 & 5 & 7 & 8 & 9 & 10 & 11 & 12 & \\
\hline Accipiter brevipes & & & & & & & 4 & 5 & 3 & & & 12 \\
\hline Accipiter nisus & & & 1 & & & & 1 & 43 & 32 & & & 77 \\
\hline Aquila chrysaetos & & 1 & 2 & & & & & 2 & 1 & 1 & & 7 \\
\hline Aquila clanga & & & 5 & 7 & 2 & & 7 & 11 & 3 & & 1 & 36 \\
\hline Aquila pomarina & & & 3 & 13 & 2 & & 1 & 29 & 2 & & & 50 \\
\hline $\begin{array}{l}\text { Aquila clanga }+ \\
\text { A. pomarina }\end{array}$ & & 2 & 5 & 7 & & & 1 & 6 & 1 & & & 22 \\
\hline Aquila heliaca & & & 1 & 1 & & & 1 & 9 & 1 & & & 13 \\
\hline Aquila nipalensis & & & & 1 & & 1 & & 1 & & & & 3 \\
\hline Buteo buteo & & 14 & 44 & 84 & & & 35 & 561 & 247 & 4 & & 989 \\
\hline Buteo lagopus & 9 & 60 & 74 & 19 & & & & & 57 & 20 & 55 & 294 \\
\hline Buteo rufinus & & & 1 & & & & 3 & 3 & 5 & & & 12 \\
\hline Circaetus gallicus & & & & & 1 & & 1 & 5 & & & & 7 \\
\hline Circus aeruginosus & & & 2 & 4 & & & 7 & 24 & 1 & & & 38 \\
\hline Circus cyaneus & & 4 & 1 & 2 & & & & 1 & 20 & & & 28 \\
\hline Circus macrourus & & & & 4 & & & 3 & 3 & & & & 10 \\
\hline Circus pygargus & & & & 1 & & & 4 & 10 & 1 & & & 17 \\
\hline Falco cherrug & & & 1 & 1 & & & & 5 & 2 & & & 9 \\
\hline Falco columbarius & & & & 1 & & & & 1 & 6 & 1 & & 9 \\
\hline Falco peregrinus & & 1 & 1 & & & & 2 & 2 & 5 & & & 11 \\
\hline Falco rusticolus & & 1 & & & & & & & & & & 1 \\
\hline Falco subbuteo & & & & 3 & 1 & & 14 & 147 & 15 & & & 180 \\
\hline Falco tinnunculus & & & 1 & & & & 3 & 44 & 2 & & & 50 \\
\hline Falco vespertinus & & & & & 6 & & 2 & 22 & & & & 30 \\
\hline Haliaeetus albicilla & & & 2 & & & & & & 2 & 1 & & 5 \\
\hline Hieraaetus pennatus & & 1 & & 4 & & & 8 & 45 & 2 & & & 60 \\
\hline Milvus migrans & & & & 12 & & & 8 & 9 & & & & 29 \\
\hline Pandion haliaetus & & & & 5 & & & 1 & 7 & 3 & & & 16 \\
\hline Pernis apivorus & & & & 13 & 19 & & 195 & 116 & 10 & & & 353 \\
\hline Bcero / Total & 9 & 84 & 144 & 183 & 31 & 1 & 301 & 1111 & 421 & 27 & 56 & 2368 \\
\hline
\end{tabular}

мые поздние регистрации мамых подорликов известны во второй половине октября - 20 и 21.10.2012 (см. табл. 4).

Беркуты отмечены в основном в марте и сентябре: на эти месяцы приходится по 30 \% регистраций. На мекабрь, ноябрь, февраиь и октябрь приходится по $10 \%$ регистраций.

Три регистрации степного орла были в апреле, июле и сентябре.

Основная масса регистраций мигрируюших могильников приходится на сентябрь.

Большая часть регистраций (75 \%) орлакарлика в осенний сезон слелана в сентябре.

Хорошо изучены сроки осенних миграционных перемешений обыкновенного канюка: 55 \% всех регистраций вида на миграциях (как осенних, так и весенних) приходится на сентябрь и $25 \%$ - на октябрь. В августе, марте и апреле отмечено по $5 \%$ регистраций. while in autumn they prefer ecotones of open landscapes.

For Lesser Spotted Eagle the most important habitats during migration are ecotone between alder forest, meadow and upland oak forest; ecotone between open floodplains and pine forest; floodplain meadows; settlements of different types and outskirts; ecotone between wooded floodplain and bedrock river slopes covered with pine forest.

For Greater Spotted Eagle the most important habitats during migration are upland oak forests with boggy ravines; big marshes in riverbeds; ecotone between alder forest, meadow and upland oak forest; ecotone of pine forest and open floodplain; wooded floodplain with small bogs; alder forest; fields.

Both species of Spotted Eagles used the whole variety of preferable habitats only in autumn. In spring they mostly seek biotopes connected with floodplains. 
Распределение мигрируюших зимняков по месяцам достаточно равномерно: по $25 \%$ приходится на октябрь и март, $20 \%$ - сревраль и 15 \% - декабрь.

Осенние встречи мигрируюших курганников также Аостаточно равномерны: $33 \%$ приходится на октябрь, по $30 \%$ - на сентябрь и август. Встречи в весенний период (март) крайне редки.

Змееяды в период миграций отмечены в сентябре (70 \%) и, гораздо реже, в августе (15\%) и мае (15\%).

Регистрации мигрируюших осоедов распределены межлу сентябрем (55 \%) и августом (35\%), незначительное число приходится на октябрь и на весенние месяцы.

Чёрные коршуны на миграциях отмечены в апреле, августе и сентябре. Распределение между этими месяцами равномерно.

Выраженные миграционные перемешения орланов-белохвостов отмечены в марте и октябре - по $40 \%$, реже - в ноябре (20\%).

Полевые луни в осенний сезон отмечены в основном в октябре - 4/5 всех осенних регистраций вида. Весенние миграции происходят преимушественно в феврале и марте.

Осенние миграции степного луня в равной мере распределены между августом и сентябрем, а в весенний период этот виА летит в апреле.

Болотные муни на осенних миграциях встречаются в основном в течение сентября - около 2/3 всех регистраций мигрируюших особей этого вида. Птиц отмечами преимушественно в течение 1 и 2 декал этого месяца.

Ауговые луни в осенний сезон летят преимушественно в сентябре (60\%) и августе (30\%).

Миграции ястребов хорошо выражены в осенний сезон: тювики летят преимушественно в августе и сентябре (по $40 \%$ регистраций), гораздо реже - в начале октября (20 \%). Перепелятники же мигрируют преимушественно в сентябре (60\%) и октябре (35 \%).

У соколов осенние миграции наиболее выражены в сентябре и октябре. К первой группе относятся обыкновенная пустельга (70\% регистраций против $15 \%$ в августе и $10 \%$ в октябре), чеглок (80\% против $10 \%$ в октябре и $7 \%$ в августе) и бамобан (60\% всех регистраций мигрируюших птиц как весной, так и осенью, против $20 \%$ в октябре и по $10 \%$ - в марте и апреле). Мигрируюших кобчиков чаше всего отмечаии в сентябре (70 \% ре-
For Hen Harriers the major biotopes on migration are fields, steppes, floodplain marshes and meadows, forests glades, and big marshes in riverbeds.

Montagu's Harrier prefers floodplain meadows, fields and less often steppes in autumn, and in spring - outskirts of settlements, and ecotones between upland oak groves, meadows, and sparse grown forests.

Pallid Harrier prefers big marshes in riverbeds, floodplain meadows, steppes and less often fields.

Common Buzzard prefers a wide range of habitats. The most important biotopes in spring are fields, steppes and woodlands, and in autumn - meadows and forest edg es. In both seasons important role plays open areas inside woodlands such as clearings, forest glades and lake shores.

For Rough-Legged Buzzard the most important habitats during migration are ecotones between meadows and upland oak groves; floodplains of small rivers; ecotones between woodlands and settlements; ecotones of floodplain meadows and dry meadows; ecotones of open floodplains and fields; and woodlands with clearings and glades.

Honey Buzzard prefers ecotone of fields and upland oak groves, as well as fields and forests in spring. During autumn migration the number of habitats Honey Buzzards used for stopovers is much higher.

\section{Population dynamics, annual fluctua-} tions

Data on Raptors' annual number fluctuation is presented on fig. 9.

Overall patterns:

- a pronounced depression of many migrating species especially myophagus was observed in 2013;

- number of migrating large birds of prey with non-specialized food preferences are relatively stable between years;

- the number of migrating myophagus (buzzards, harriers) was maximum in 2014-2015; relatively high numbers were observed also in 2011-2012. Depression was observed in 2013.

- The number of migrating ornythophagus was relatively stable through the years of study; a peak number was observed in 2012; the lowest number - in 2013.

- in total, the maximum number of migrants was observed in 2014-2015, and to a lesser extent in 2010-2012 and 2016 (50-75\% of the maximum number). The minimum numbers were observed in 2005-2006 and 2013 when the number of migrating birds makes only $10-15 \%$ of the maximum numbers. 
Табл. 4. Основные фенологические явления и их даты.

Table 4. The main phenological events and dates.

\begin{tabular}{|c|c|c|c|c|c|c|}
\hline Вим / Species & $\begin{array}{r}\text { Начало } \\
\text { осенней } \\
\text { миграции } \\
\text { Beginning of } \\
\text { an autumn } \\
\text { migration } \\
\end{array}$ & $\begin{array}{r}\text { Пик осенней миграции } \\
\text { Peak of an autumn migration }\end{array}$ & $\begin{array}{r}\text { Окончание } \\
\text { осенней } \\
\text { миграции } \\
\text { Ending of } \\
\text { an autumn } \\
\text { migration } \\
\end{array}$ & $\begin{array}{r}\text { Начало } \\
\text { весенней } \\
\text { миграции } \\
\text { Beginning of a } \\
\text { spring migra- } \\
\text { tion } \\
\end{array}$ & $\begin{array}{r}\text { Пик весенней } \\
\text { миграции } \\
\text { Peak of a spring } \\
\text { migration }\end{array}$ & $\begin{array}{r}\text { Окончание } \\
\text { весенней } \\
\text { миграции } \\
\text { Ending of } \\
\text { a spring } \\
\text { migration }\end{array}$ \\
\hline 1 & 2 & 3 & 4 & 5 & 6 & 7 \\
\hline Accipiter brevipes & $\begin{array}{l}24.08 .14 \\
28.08 .15\end{array}$ & $10-25.09$ & $\begin{array}{r}\text { Нет данных } \\
\text { No data }\end{array}$ & 10.04 .07 & $\begin{array}{r}\text { Нет данных } \\
\text { No data }\end{array}$ & $\begin{array}{r}\text { Нет данных } \\
\text { No data }\end{array}$ \\
\hline Accipiter nisus & $\begin{array}{l}15.09 .08 \\
11.09 .10 \\
12.09 .11 \\
03.09 .12 \\
29.08 .14 \\
28.08 .15 \\
06.09 .16\end{array}$ & $\begin{array}{r}13.09,06.10 .10 \\
17.09,02.10,22.10 .12 \\
02.10 .14 \\
15.09 .15 \\
12.10 .16\end{array}$ & $\begin{array}{l}30.10 .13 \\
21.10 .14 \\
20.10 .15 \\
26.10 .16\end{array}$ & $\begin{array}{r}\text { Нет данных } \\
\text { No data }\end{array}$ & $\begin{array}{r}\text { Нет данных } \\
\text { No data }\end{array}$ & $\begin{array}{l}\text { Нет данных } \\
\text { No data }\end{array}$ \\
\hline Aquila chrysaetos & $\begin{array}{r}06.09 .10 \\
01-03.09 .14\end{array}$ & $01-03.09,04.11 .14$ & * & * & $\begin{array}{l}24.02 .10 \\
04.03 .11\end{array}$ & 19.03 .15 \\
\hline Aquila clanga & $\begin{array}{l}28.08 .03 \\
12.09 .09 \\
07.09 .10 \\
29.08 .14 \\
06.08 .15 \\
29.08 .16\end{array}$ & $\begin{array}{r}13-20.09 .09 \\
27.09 .16\end{array}$ & $\begin{array}{l}10.10 .07 \\
06.10 .09 \\
11.12 .10 \\
21.10 .14\end{array}$ & $\begin{array}{l}01.03 .03 \\
23.03 .05 \\
24.02 .08 \\
19.03 .11 \\
15.03 .14 \\
16.03 .15\end{array}$ & $\begin{array}{l}05.04 .05 \\
06.04 .15\end{array}$ & $\begin{array}{l}05.05 .06 \\
03.05 .11 \\
20.04 .13 \\
15.05 .14 \\
24.04 .15\end{array}$ \\
\hline Aquila heliaca & $\begin{array}{l}04.09 .10 \\
04.09 .12 \\
01.09 .14\end{array}$ & $\begin{array}{l}12.09 .11 \\
10.09 .12\end{array}$ & $\begin{array}{l}22.09 .03 \\
03.10 .12\end{array}$ & $\begin{array}{l}23.03 .05 \\
15.03 .08 \\
21.03 .09\end{array}$ & $\begin{array}{r}\text { Нет данных } \\
\text { No data }\end{array}$ & 14.04 .16 \\
\hline Aquila pomarina & $\begin{array}{l}19.08 .08 \\
13.09 .09 \\
07.09 .10 \\
14.09 .11 \\
30.08 .12 \\
26.08 .13 \\
29.08 .14\end{array}$ & $\begin{array}{r}15.09 .08 \\
18-20.09 .09\end{array}$ & $\begin{array}{l}06.10 .10 \\
20.10 .12\end{array}$ & $\begin{array}{l}15.03 .08 \\
21.03 .11 \\
15.03 .13 \\
28.02 .14\end{array}$ & $\begin{array}{r}10.04 .10 \\
07-24.04 .11\end{array}$ & $\begin{array}{l}02.05 .05 \\
20.04 .07 \\
30.04 .09 \\
24.04 .11 \\
04.05 .15\end{array}$ \\
\hline Buteo buteo & $\begin{array}{l}11.09 .09 \\
29.08 .10 \\
13.08 .12 \\
24.08 .14 \\
20.08 .15 \\
22.08 .16\end{array}$ & $\begin{array}{r}10,26.09 \\
11-16.10 .03,29.09,08,15-23.10 .07 \\
15,26-27.09 \\
19.10 .08 \\
11-24.09 .09 \\
07-12,20.09 .10 \\
14.09 .2011 \\
04,17.09 \\
03,21.10 .12 \\
15-25.09,02-03,11.10 .14 \\
28.08,07-13,17-23.09,01-07.10 .15 \\
26.08,06-10,12-14.10 .2016\end{array}$ & $\begin{array}{l}23.10 .07 \\
30.10 .13 \\
31.10 .14\end{array}$ & $\begin{array}{l}19.03 .04 \\
07.03 .05 \\
18.02 .07 \\
24.02 .10 \\
20.03 .11 \\
28.02 .14 \\
08.03 .15 \\
26.02 .16\end{array}$ & $\begin{array}{r}10.03 .03 \\
12.04 .04 \\
30.03 .05 \\
13.04 .06 \\
15.03 .08 \\
30.03,13-14.04 .10 \\
15.03-10.04 .13 \\
10-20.04 .14 \\
16.03 .15\end{array}$ & $\begin{array}{l}22.04 .14 \\
20.04 .15 \\
20.04 .16\end{array}$ \\
\hline Buteo lagopus & $\begin{array}{l}30.10 .03 \\
17.11 .07 \\
29.10 .09 \\
28.11 .10 \\
11.10 .12 \\
06.10 .14 \\
09.10 .15 \\
12.10 .16\end{array}$ & $\begin{array}{r}01.11 .04 \\
17.11 .07 \\
05.11 .08 \\
25.12 .10 \\
12.12 .12 \\
17-19.10,30.12 .14 \\
28-29.10,04.12 .15\end{array}$ & 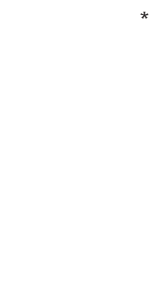 & . & $\begin{array}{r}29.03 .03 \\
08,24.02 .04 \\
07,11,23.03 .05 \\
27.03 .06 \\
02,26.02 .07 \\
24-25.02,05.03 .10 \\
07.02,13-21,31.03 .11 \\
25.02,02,16.03 .15 \\
17-18,20.01,26.02 .16\end{array}$ & $\begin{array}{l}23.03 .05 \\
05.03 .10 \\
13.04 .11 \\
27.03 .13 \\
30.03 .14 \\
29.02 .16\end{array}$ \\
\hline Buteo rufinus & $\begin{array}{l}19.08 .14 \\
04.09 .12\end{array}$ & 19.09.2009 & 22.10 .12 & 21.03 .14 & $\begin{array}{r}\text { Нет данных } \\
\text { No data }\end{array}$ & $\begin{array}{r}\text { Нет данных } \\
\text { No data }\end{array}$ \\
\hline Circaetus gallicus & 20.08 .15 & $\begin{array}{r}13.09 .2011 \\
12.09 .04\end{array}$ & 22.09 .14 & $\begin{array}{r}\text { Нет данных } \\
\text { No data }\end{array}$ & $\begin{array}{r}\text { Нет данных } \\
\text { No data }\end{array}$ & 04.05 .16 \\
\hline Circus aeruginosus & $\begin{array}{l}12.09 .11 \\
06.09 .12 \\
29.08 .14 \\
13.08 .15 \\
26.08 .16\end{array}$ & $\begin{array}{r}10-25.09 .12 \\
10-15.09 .15 \\
25.08 .16\end{array}$ & 28.09 .14 & $\begin{array}{l}31.03 .11 \\
01.04 .13 \\
03.04 .14 \\
03.04 .15\end{array}$ & $\begin{array}{r}\text { Нет данных } \\
\text { No data }\end{array}$ & $\begin{array}{r}\text { Нет данных } \\
\text { No data }\end{array}$ \\
\hline Circus cyaneus & $\begin{array}{l}30.10 .05 \\
04.10 .08 \\
12.10 .09 \\
19.09 .10 \\
03.10 .12 \\
27.10 .14 \\
08.10 .16\end{array}$ & $\begin{array}{r}11.10 .08 \\
15.10 .09 \\
27-31.10 .14 \\
24.10 .16\end{array}$ & * & * & 25.02 .14 & $\begin{array}{l}28.03 .05 \\
06.04 .10 \\
03.04 .11 \\
15.03 .13\end{array}$ \\
\hline
\end{tabular}


Продолжение табл. 4.

Table 4.

\begin{tabular}{|c|c|c|c|c|c|c|}
\hline 1 & 2 & 3 & 4 & 5 & 6 & 7 \\
\hline Circus macrourus & $\begin{array}{l}13.08 .08 \\
04.09 .12 \\
19.09 .14 \\
06.08 .15\end{array}$ & $10-15.09 .13$ & 29.09 .14 & $\begin{array}{l}03.04 .11 \\
02.04 .15\end{array}$ & 14.04 .15 & 24.04 .15 \\
\hline Circus pygargus & $\begin{array}{l}13.09 .10 \\
24.08 .14 \\
12.08 .15\end{array}$ & $\begin{array}{r}20.09 .10 \\
12.09 .11 \\
19.09 .12 \\
14.09 .14 \\
03.09,10.09 .15\end{array}$ & 29.09 .12 & 01.04 .13 & $\begin{array}{r}\text { Нет данных } \\
\text { No data }\end{array}$ & $\begin{array}{r}\text { Нет данных } \\
\text { No data }\end{array}$ \\
\hline Falco cherrug & 08.09 .15 & $\begin{array}{l}24-29.09 .12 \\
25-27.09 .16\end{array}$ & 06.10 .16 & 30.03 .05 & $\begin{array}{r}\text { Нет данных } \\
\text { No data }\end{array}$ & $\begin{array}{r}\text { Нет данных } \\
\text { No data }\end{array}$ \\
\hline Falco columbarius & $\begin{array}{l}20.08 .08 \\
06.10 .14 \\
01.10 .16\end{array}$ & $\begin{array}{l}16-21.10 .15 \\
06-08.10 .16\end{array}$ & * & * & $\begin{array}{r}\text { Нет данных } \\
\text { No data }\end{array}$ & 20.04 .15 \\
\hline Falco peregrinus & $\begin{array}{l}03.10 .12 \\
08.09 .14 \\
31.08 .15 \\
28.09 .16\end{array}$ & $\begin{array}{r}08.10 .14 \\
17-21.10 .15 \\
16.10 .16\end{array}$ & * & * & 05.03 .11 & 28.02 .14 \\
\hline Falco subbuteo & $\begin{array}{l}15.09 .08 \\
11.09 .09 \\
06.09 .10 \\
14.09 .11 \\
03.09 .12 \\
19.08 .14 \\
20.08 .15 \\
26.08 .16\end{array}$ & $\begin{array}{r}27.09,01-04.10 .08 \\
25.09 .09 \\
10-12,20-26.09 .10 \\
06,17-20.09 .12 \\
20-25.09 .14 \\
07-23.09 .15\end{array}$ & $\begin{array}{l}15.10 .09 \\
02.10 .12 \\
27.09 .14 \\
03.10 .16\end{array}$ & $\begin{array}{l}01.04 .13 \\
18.04 .14\end{array}$ & $\begin{array}{r}\text { Нет данных } \\
\text { No data }\end{array}$ & $\begin{array}{l}\text { Нет данных } \\
\text { No data }\end{array}$ \\
\hline Falco tinnunculus & $\begin{array}{l}04.09 .10 \\
14.09 .11 \\
08.09 .14 \\
10.08 .15\end{array}$ & $\begin{array}{l}26.09 .10 \\
28.08 .15\end{array}$ & $\begin{array}{r}\text { Нет данных } \\
\text { No data }\end{array}$ & 27.03.07 & $\begin{array}{r}\text { Нет данных } \\
\text { No data }\end{array}$ & $\begin{array}{r}\text { Нет данных } \\
\text { No data }\end{array}$ \\
\hline Falco vespertinus & $\begin{array}{l}31.08 .14 \\
12.08 .15 \\
06.09 .16\end{array}$ & $\begin{array}{l}14.09 .12 \\
07.09 .16\end{array}$ & $\begin{array}{l}28.09 .14 \\
19.09 .16\end{array}$ & $\begin{array}{r}\text { Нет данных } \\
\text { No data }\end{array}$ & 13.05 .16 & 22.05 .14 \\
\hline Haliaeetus albicilla & $\begin{array}{r}\text { Нет данных } \\
\text { No data }\end{array}$ & $\begin{array}{l}02.10 .12 \\
04.10 .16\end{array}$ & 02.11 .12 & 20.02 .15 & 08.03.15 & $\begin{array}{r}\text { Нет данных } \\
\text { No data }\end{array}$ \\
\hline $\begin{array}{l}\text { Hieraaetus } \\
\text { pennatus }\end{array}$ & $\begin{array}{l}13.09 .09 \\
04.09 .10 \\
12.09 .11 \\
04.09 .12 \\
21.08 .14 \\
28.08 .15 \\
26.08 .16\end{array}$ & $\begin{array}{r}17.09 .05 \\
10-15.09 .08 \\
10-20.09 .09 \\
07-11,20.09 .10 \\
04-06.09 .12 \\
28.08,07-15.09 .15\end{array}$ & $\begin{array}{l}02.10 .12 \\
22.09 .14\end{array}$ & $\begin{array}{l}01.04 .13 \\
28.02 .14 \\
01.04 .15 \\
01.04 .16\end{array}$ & $\begin{array}{r}\text { Нет данных } \\
\text { No data }\end{array}$ & $\begin{array}{r}\text { Нет } а \text { анных } \\
\text { No data }\end{array}$ \\
\hline Milvus migrans & $\begin{array}{l}06.09 .10 \\
04.09 .12 \\
29.08 .14 \\
25.08 .15 \\
24.08 .16\end{array}$ & $\begin{array}{r}19-20.09 .09 \\
07.09 .10\end{array}$ & $\begin{array}{r}\text { Нет данных } \\
\text { No data }\end{array}$ & $\begin{array}{l}02.04 .11 \\
01.04 .13 \\
07.04 .14\end{array}$ & $\begin{array}{r}\text { Нет данных } \\
\text { No data }\end{array}$ & $\begin{array}{r}\text { Нет данных } \\
\text { No data }\end{array}$ \\
\hline Pandion haliaetus & 17.08 .16 & $\begin{array}{r}29.09 .07 \\
21.09 .15 \\
02,09,13,27.09 .16\end{array}$ & $\begin{array}{l}03.10 .12 \\
20.10 .14 \\
12.10 .16\end{array}$ & 08.04 .14 & $\begin{array}{l}13.04 .13 \\
14.04 .14\end{array}$ & 30.04 .05 \\
\hline Pernis apivorus & $\begin{array}{l}03.09 .12 \\
19.08 .14 \\
08.08 .15 \\
10.08 .16\end{array}$ & $\begin{array}{r}15.09 .08 \\
19.09 .09 \\
04-07.09 .10 \\
04-18.09 .12 \\
01-10.09 .14 \\
25-28.08,07,23.09 .15 \\
26-27.08 .16\end{array}$ & $\begin{array}{l}29.09 .07 \\
11.10 .08 \\
12.10 .09 \\
18.09 .14 \\
07.10 .15\end{array}$ & $\begin{array}{l}29.04 .09 \\
28.04 .13 \\
21.04 .14 \\
28.04 .15\end{array}$ & $\begin{array}{r}30.04-01.05 .09 \\
10-11.05 .10 \\
10.05 .15\end{array}$ & $\begin{array}{l}11.05 .09 \\
25.05 .14\end{array}$ \\
\hline
\end{tabular}

Примечание / Note:

* миграции трудноотделимы от зимовок / Difficulties in separating migratory individuals from wintering ones.

гистраций), гораздо реже - в августе (20\%) и мае (10\%). Во вторую группу можно отнести такие виды, как дербник (70 \% всех годовых мигрантов приходится на октябрь и лишь по $10 \%$ - на ноябрь, сентябрь и апрель), сапсан (45\%, против $20 \%$

\section{Population dynamics by species}

The number of Greater and Lesser Spotted Eagles was relatively stable during our study. The maximum number of Lesser Spotted Eagles was observed in 2007 when we got about $20 \%$ of the total num- 
в августе и $20 \%$ - в сентябре, $15 \%$ - в весенние месяцы).

В период с 2012 г. по 2016 г. отмечено смешение начаяа и пиков осенней миграции у некоторых видов на более ранние сроки. Так, пик миграции осоедов переместился с первой половины - средины сентября на вторую половину августа - начамо сентября, а начамо миграции - с 18-20 августа на 1-10 августа; начамо миграции чёрных коршунов - с начала сентября - на средину августа; начало миграции чеглока - с начала сентября на средину августа; начамо миграции обыкновенного канюка и болотного муня - с 5-7 сентября на 10-20 августа. ИАет увеличение августовских встреч кобчиков и степных муней, соответственно, сокрашение таковых - в сентябре.

Мы провели сравнение сроков и характера миграций хишных птиц в наше время (2005-2016 годы) с таковыми из монограсии Н.Н. Сомова (1897) - конец 19 века. Этот автор отметил невыраженную осеннюю миграцию чёрного коршуна: птицы перемешаяись неинтенсивно, преимушественно - в одиночку, реже парами или группами; основные миграционные перемешения - в течение 3-й декады августа и первой половины сентября (начамо весенней миграции - в начале апреля, окончание осенней миграции - в конце сентября - первых числах октября). Такова же ситуация и в наши дни. Отмечена невыраженная весенняя миграция перепелятников, скорее - прерываюшиеся кочевки на протяжении марта. Осенние миграции выражены, в течение всего сентября с пиком в начале - средине сентября. Наши наблюдения дают идентичную картину. Мигрируюшие балобаны, как в 19 веке, так и в 21 веке отмечены во 2-й -

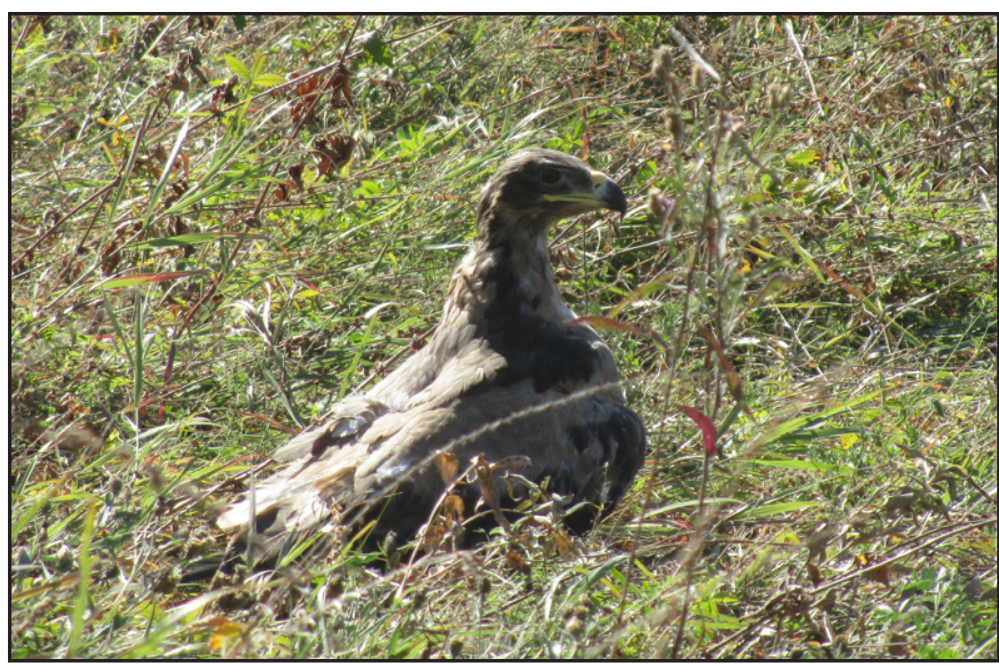

ber of Lesser Spotted Eagles counted during the study.

Eastern Imperial Eagles were observed regularly in small numbers (2-3 specimens per year) except for 2016 when no Imperial Eagles were observed.

Golden Eagles were noted on migration in 2004, 2005, 2010, 2012 and 2014 (2 registrations per season).

Steppe Eagles were registered only in 2011 and 2016 (a Steppe Eagle observed in 2015 , July 25 is probably a nomadic nonbreeding bird).

For Booted Eagle maximum was observed in 2012 and 2015 (more than $30 \%$ of Booted Eagles counted during the 10 years of study per each) and minimum - in 2013 and 2016.

Short-Toed Eagle is a non-regular migrant in the region. About $40 \%$ of all Short-Toed Eagles were registered in 2015. It was also noted in 2007, 2011, 2012, and 2014.

Common Buzzards were at maximum numbers in 2010, 2014, 2015 and 2016, and minimum in 2013.

Rough-Legged Buzzards were at the maximum in 2010 (20\% of the total number of this species counted in 10 years of study) and 2015 (30\%), and at the minimum in 2012-2013.

For Long-Legged Buzzard we mainly registered a one bird per year since this species is rare in Kharkiv region. But in 2011-2012 and 2014 we noted an increasing number of Long-Legged Buzzards. In 2013 and 2015-2016 we didn't observe the species.

For Honey Buzzard we got the minimum number in 2008 and 2009 (less than $10 \%$ of the total number of the species per each) and maximum in 2016 (25 \% form all Honey Buzzards counted during the 10 years of study).

Black Kites showed minimal numbers on migration in 2012-2014. In other years its numbers were uniform.

For Hen Harrier maximum was registered in 2014 and 2016 (25\% of the total number per each). In other years the species number was uniform but low.

Степной орёл (Aquila nipalensis), около с. Нижний Бишкин (окрестности Национаиьного природного парка "Гомольшанские леса", Змиевский район Харьковской области). Фото С. Витера.

Steppe Eagle (Aquila nipalensis) near Nyjnyi Bishkin village (National nature park "Gomilshansky Lisy", Zmyiv district, Kharkiv region). Photo by S. Viter. 
3-й мекаме сентября. Пик миграции скопы в 19 веке отмечен в конце марта - начаме апреля, в 21 веке - в начале - средине апреля; сроки осенней миграции не претерпели изменений. Н.Н. Сомов отмечал массовую осеннюю миграцию орлановбелохвостов: 19.10.1879 г. (старый стиль) в течение часа наблюдений отмечено около 40 птиц (Сомов, 1897); в настоящее время выраженной миграции орлановбелохвостов не отмечено, а перемешения носят характер кочевок в течение октября - декабря и в феврале. Сроки осенней миграции перепелятников и тювиков не претерпели изменений. Мигрируюших сапсанов осенью в 19 веке отмечами в течение сентября - начаме октября, а в 21 веке - с конца августа до средины ноября, т.е. произошло расширение сроков осенней миграции за счет вкАючения в осенний миграционный период большей части октября и ноября. Сроки осенних и весенних миграций чеглока и змееяла, а также осенних и весенних миграций большого подорлика сушественно не изменились. Осенние миграции дербников отмечены Н.Н. Сомовым (1897) в течение сентября, нами же мигрируюшие птицы отмечены в конце сентября - начале ноября, т.е. в значительно более позАние сроки.

\section{5. Направяение и высота перемеше- ния транзитных мигрирующих хищных птиц \\ Осенние миграции}

Преоблахаюшим направлением осенних миграций является юг, юго-восток и югвосток-юг, реже встречаются запацное, юго-запанное и прочие направления румбов секции "запад - юг - восток" (рис. 6).

В южном направлении осенью перемешаются более 50 \% учтённых нами особей осоелов, все отмеченные нами мигрируюшие скопы, 45 \% луговых луней, 45 \% орлов-карликов, 25 \% чёрных коршунов, 2/3 обыкновенных пустельг, 60 \% обыкновенных канюков, европейских тювиков и чеглоков, 40 \% полевых муней, 50 \% малых подорликов и перепелятников.

В юг-восток-южном направлении происходит миграция фрактически всех отмеченных степных муней, 40 \% полевых муней и курганников, 70 \% болотных муней.

Юго-восточное направление является искАючительным Аля змееялов (100\%), 40 \% курганников, 30 \% мамых подорликов и орлов-карликов, 45 \% больших подорликов, 20 \% перепелятников и европейских тювиков
About $70 \%$ of all Pallid Harriers were observed in 2014 and 2015. Later, in 2016 we did not register this species.

About half of all Montagu's Harriers were counted in 2015. In other years its number was uniform.

For Marsh Harrier maximum was registered in 2014-2015 (20-25\% of the total number per each) and minimum - in 20072009 and 2013. In 2016 number of migrating Marsh Harriers made a 2.5-fold decrease comparing with years of maximum.

For Sparrowhawk maximum was registered in 2012 (about 1/3 of all registrations of this species) and 2016 (about $20 \%$ ); only a few individuals of this species were observed during migrations in 2013 that became a year of the minimum. In other years the species number was uniform.

Levant's Sparrowhawks were observed on autumn migration in 2011, 2012, 20142016, and in spring of 2007.

Osprey was observed regularly in the numbers not exceeding 10 individuals per season. In 2016 we observed a sharp increase in the number of the species when not less than 16 individuals were registered on migration in the National Nature Park "Gomilshansky Lisy".

For Common Kestrel minimum was noted in the period before 2007 (including 2007) and in autumn of 2016.

For Eurasian Hobby maximum was registered in 2011, 2012 and 2015 (25\% of the total number per each); in 2014 and 2016 we observed a decrease in the number of migrants (10\% of the total number per each), and the depression of the species was noted in 2007-2009 and 2013.

More than $80 \%$ of all registrations of Redfooted Falcon were done in 2014-2016 that along with the finding of 3-4 new breeding sites provides good evidence of population growth in Eastern Europe after a long depression.

Saker Falcon is a non-regular migrant that was observed in 2011, 2012, 2015 and 2016. Before 2011 we didn't have registrations of this species on migration.

\section{Conclusions}

1. The dominant species of migration is Common Buzzard with $32.4 \%$ of all raptors registrations. Subdominant species are Rough-legged Buzzard (14.43\%), Honey Buzzard (10.05 \%) and Hobby (10.55 \%).

2. Most of the birds of prey pass through the region as segregate individuals, seldom - in small groups and rarely in flocks. 


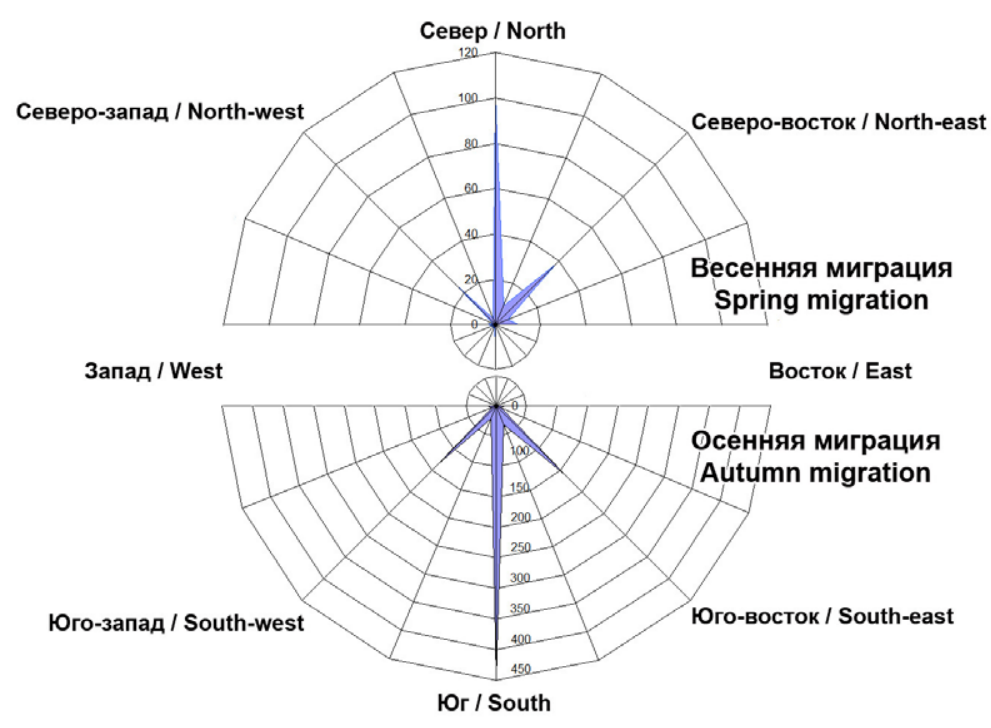

На западное направление приходится около 50 \% всех регистраций кобчиков и $25 \%$ степных луней, а на югозапанное - 50 \% регистраций дербников, $20 \%$ тювиков и все регистрации
Рис. 6. Направление миграции хишных птиц (особи).

Fig. 6. Migration directions (number of individuals per direction).

3. The species most prone to making a mixed flock is a Lesser Spotted Eagle - $20 \%$ of all individuals of this species were found in mixed flocks.

4. Transit migration prevails over migration stopovers in the region for 18 out of 27 raptor species. For instance, about 2/3 of Common Buzzards and Booted Eagles, $90 \%$ of Honey Buzzards, $60 \%$ of Golden Eagles, Levant's Sparrowhawks and Hobbies, $70 \%$ of Imperial Eagles and Common Kestrels and $65 \%$ of Lesser Spotted Eagles are passing the region in transit.

5. The most intensive migration appeared in the second half of August, Sep-

Табл. 5. Направление миграции хищных птиц (регистрации).

Table 5. Migration directions (number of registrations per direction).

\begin{tabular}{|c|c|c|c|c|c|c|c|c|c|c|c|c|c|c|c|c|}
\hline \multirow[b]{2}{*}{ Вим / Species } & \multicolumn{16}{|c|}{ Направление весенней миграции / Direction of spring migration } \\
\hline & $\begin{array}{l}\mathbf{C} \\
\mathbf{N} \\
0\end{array}$ & $\begin{array}{l}\text { CCB } \\
\text { NNE } \\
22.5 \\
\end{array}$ & $\begin{array}{l}\text { CB } \\
\text { NE } \\
45 \\
\end{array}$ & $\begin{array}{l}\text { CBB } \\
\text { NEE } \\
67.5 \\
\end{array}$ & $\begin{array}{c}\mathbf{B} \\
\mathbf{E} \\
90 \\
\end{array}$ & $\begin{array}{c}\text { BBЮ } \\
\text { EES } \\
112.5 \\
\end{array}$ & $\begin{array}{c}\text { OB } \\
\text { SE } \\
135 \\
\end{array}$ & $\begin{array}{l}\text { OЮB } \\
\text { SSE } \\
157.5 \\
\end{array}$ & $\begin{array}{c}\mathbf{1 O} \\
\mathbf{S} \\
180 \\
\end{array}$ & $\begin{array}{c}\text { IOHO3 } \\
\text { SSW } \\
202.5 \\
\end{array}$ & $\begin{array}{l}\text { 103 } \\
\text { SW } \\
225 \\
\end{array}$ & $\begin{array}{l}\text { 1033 } \\
\text { SWW } \\
247.5 \\
\end{array}$ & $\begin{array}{c}\mathbf{3} \\
\mathbf{w} \\
270 \\
\end{array}$ & $\begin{array}{c}\text { C33 } \\
\text { NWW } \\
292.5\end{array}$ & $\begin{array}{l}\text { C3 } \\
\text { NW } \\
315 \\
\end{array}$ & $\begin{array}{l}\text { CC3 } \\
\text { NNW } \\
337.5 \\
\end{array}$ \\
\hline Accipiter nisus & & & & & & & & & & & & & & & & 1 \\
\hline Aquila chrysaetos & 1 & & & & 1 & & & & & & & & & & & \\
\hline Aquila heliaca & 1 & & & & & & & & & & & & & & 1 & \\
\hline Aquila nipalensis & & & 1 & & & & & & & & & & & & & \\
\hline Aquila clanga & 2 & & 1 & & & & & & & & & & & & & \\
\hline Aquila pomarina & 2 & & 2 & & 1 & & 1 & & & & & & 2 & & 1 & 1 \\
\hline $\begin{array}{l}\text { Aquila clanga/ } \\
\text { pomarina sp. }\end{array}$ & 2 & & 1 & & 1 & & & & & & & & & & 3 & 1 \\
\hline Buteo buteo & 36 & & 8 & 4 & 2 & & & & & & & & & 1 & 5 & 1 \\
\hline Buteo lagopus & 34 & 7 & 12 & 1 & 3 & & & & 10 & 1 & 2 & 1 & 3 & & 9 & \\
\hline Buteo rufinus & 1 & & & & & & & & & & & & & & & \\
\hline Circus aeruginosus & 4 & & & & & & & & & & & & & & & \\
\hline Circus cyaneus & 1 & & 2 & & & & & & & & & & & & & \\
\hline Circus macrourus & & & 1 & & 1 & & & & & & & & & & & \\
\hline Circus pygargus & & & 1 & & & & & & & & & & & & 1 & \\
\hline Falco cherrug & & & 1 & & & & & & & & & & & & & \\
\hline Falco columbarius & & & 1 & & & & & & & & & & & & & \\
\hline Falco peregrinus & 1 & & & & & & & & & & & & & & & \\
\hline Falco subbuteo & 2 & & & 1 & & & & & & & & & & & & \\
\hline Falco tinnunculus & & 1 & & & & & & & & & & & & & & \\
\hline Haliaeetus albicilla & 1 & & 1 & & & & & & & & & & & & & \\
\hline Hieraaetus pennatus & 2 & 1 & & & & & & & & & & & & & & \\
\hline Milvus migrans & 4 & & & & 1 & & & & & & & & & & 2 & \\
\hline Pandion haliaetus & & & 3 & & & & & & & & & & & & & \\
\hline Pernis apivorus & 7 & & 2 & & & & & & & & & & & & 3 & \\
\hline $\begin{array}{l}\text { Всего на весенней } \\
\text { миграции } \\
\text { Total during spring } \\
\text { migration }\end{array}$ & 101 & 9 & 37 & 6 & 10 & 0 & 1 & 0 & 10 & 1 & 2 & 1 & 5 & 1 & 25 & 4 \\
\hline
\end{tabular}


Продолжение табл. 5.

Table 5.

\begin{tabular}{|c|c|c|c|c|c|c|c|c|c|c|c|c|c|c|c|c|}
\hline \multirow[b]{2}{*}{ Вим / Species } & \multicolumn{16}{|c|}{ Направление осенней миграции / Direction of autumn migration } \\
\hline & $\begin{array}{l}\mathbf{C} \\
\mathbf{N} \\
0\end{array}$ & $\begin{array}{l}\text { CCB } \\
\text { NNE } \\
22.5 \\
\end{array}$ & $\begin{array}{l}\text { CB } \\
\text { NE } \\
45 \\
\end{array}$ & $\begin{array}{l}\text { CBB } \\
\text { NEE } \\
67.5 \\
\end{array}$ & $\begin{array}{c}\mathbf{B} \\
\mathbf{E} \\
90 \\
\end{array}$ & $\begin{array}{c}\text { BBЮ } \\
\text { EES } \\
112.5 \\
\end{array}$ & $\begin{array}{c}\text { FOB } \\
\text { SE } \\
135 \\
\end{array}$ & $\begin{array}{c}\text { OЮB } \\
\text { SSE } \\
157.5 \\
\end{array}$ & $\begin{array}{c}\text { Ю } \\
\mathbf{S} \\
180 \\
\end{array}$ & $\begin{array}{c}\text { OOO3 } \\
\text { SSW } \\
202.5 \\
\end{array}$ & $\begin{array}{l}\text { 103 } \\
\text { SW } \\
225 \\
\end{array}$ & $\begin{array}{l}\text { 1033 } \\
\text { SWW } \\
247.5 \\
\end{array}$ & $\begin{array}{c}\mathbf{3} \\
\mathbf{W} \\
270 \\
\end{array}$ & $\begin{array}{c}\text { C33 } \\
\text { NWW } \\
292.5 \\
\end{array}$ & $\begin{array}{l}\text { C3 } \\
\text { NW } \\
315 \\
\end{array}$ & $\begin{array}{r}\text { CC3 } \\
\text { NNW } \\
337.5 \\
\end{array}$ \\
\hline Accipiter brevipes & & & & & & & 1 & & 4 & & 1 & & & & & \\
\hline Accipiter nisus & & & & & & & 9 & 1 & 35 & 4 & 14 & & & & & \\
\hline Aquila chrysaetos & & & & & & & & & & & 2 & & & & & \\
\hline Aquila heliaca & & & & & & & 1 & 1 & 5 & & 1 & & & & & \\
\hline Aquila nipalensis & & & & & & & & & 1 & & & & & & & \\
\hline Aquila clanga & & & 1 & & 1 & 2 & 5 & 2 & 4 & & 1 & 1 & & & & \\
\hline Aquila pomarina & & & & & & & 7 & 1 & 10 & & 3 & & & & & \\
\hline $\begin{array}{l}\text { Aquila clanga/ } \\
\text { pomarina sp. }\end{array}$ & & & & & & & 1 & 1 & 3 & & 2 & & & & & \\
\hline Buteo buteo & & & 2 & & 8 & 1 & 50 & 11 & 180 & 6 & 35 & 2 & 10 & & 1 & \\
\hline Buteo lagopus & 3 & & & & & & 10 & 2 & 21 & 3 & 26 & 5 & 2 & & 1 & \\
\hline Buteo rufinus & & & & & & 1 & 3 & & 3 & & 1 & & & & & \\
\hline Circaetus gallicus & & & & & & & 1 & & & & & & & & & \\
\hline Circus aeruginosus & & & & & & & 3 & & 16 & & 2 & & & & & \\
\hline Circus cyaneus & & & & & & & 1 & 1 & 3 & & 3 & 1 & & & & \\
\hline Circus macrourus & & & & & & & 1 & 2 & & & & & 1 & & & \\
\hline Circus pygargus & & & & & & & 1 & & 6 & 2 & 3 & & & & & \\
\hline Falco cherrug & & & & & & & 1 & 1 & 1 & 1 & & & & & & \\
\hline Falco columbarius & & & & & & & & & 1 & & 1 & & & & & \\
\hline Falco peregrinus & & & & & & & 1 & & & & 2 & & & & & \\
\hline Falco subbuteo & & & & & 2 & 2 & 17 & 1 & 50 & 2 & 14 & & & & & \\
\hline Falco tinnunculus & & & & & & & 3 & & 9 & 1 & 1 & & & & & \\
\hline Falco vespertinus & & & & & & & & & & 1 & & & 1 & & & \\
\hline Haliaeetus albicilla & & & & & & & & & 1 & & 2 & & & & & \\
\hline Hieraaetus pennatus & & & & & 2 & 1 & 11 & & 20 & 1 & 4 & & & & & \\
\hline Milvus migrans & & & & & 1 & & 4 & & 3 & & 5 & & & & & \\
\hline Pandion haliaetus & & & & & & & & & 3 & & & & & & & \\
\hline Pernis apivorus & & & 1 & & 3 & & 29 & 9 & 67 & 2 & 12 & & & & & \\
\hline $\begin{array}{l}\text { Всего на осенней } \\
\text { миграции } \\
\text { Total during autumn } \\
\text { migration }\end{array}$ & 3 & 0 & 4 & 0 & 17 & 7 & 160 & 33 & 446 & 23 & 135 & 9 & 14 & 0 & 2 & 0 \\
\hline
\end{tabular}

беркутов, а также $45 \%$ регистраций чёрных коршунов.

\section{Весенние миграции}

Преобладаюшими направлениями весенних миграционных перемешений, согласно нашим наблюдениям, являются северо-восток (50 \% луговых луней, 2/3 полевых луней, 50 \% орланов-белохвостов, все скопы, цербники, бамобаны, степные луни и перепелятники, 40 \% обыкновенных канюков, больших и и малых подорликов) и север (50\% осоедов, 50 \% орланов-белохвостов, по 40 \% обыкновенных канюков, больших и малых поАорликов все обыкновенные пустельги и сапсаны, а также курганники и болотные луни, половина регистраций полевых луней и чёрных коршунов). Зимняки наиболее часто перемешаются в северо-запалном направлении (50 \% регистраций). tember, $1^{\text {st }}$ and $2^{\text {nd }}$ decades of October, and in the last decade of February and the first half of April.

6 . The main directions of the autumn migration are south, southeast, and southeast-south; of the spring migration - northeast.

7. We allocate the most important habitats for migrating birds of prey where more than $70 \%$ of all migrating raptors were observed. There are i) ecotone between floodplains of big rivers and bedrock river slopes covered with pine forest, and ii) upland oak grove marges, especially when there is a valley of a small river in the vicinity.

8 . The number of migrating birds of prey was maximum in 2014 and 2015, and to a lesser extent in 2010-2012 and 2016 (50-75\% of the maximum number), and minimum in 2005-2006 and 2013 (only $10-15 \%$ of the maximum number). 
Более детальная инсормация о направмениях миграции хишных птиц приведена в табл. 5.

\section{Высота миграционных перемещений}

На рис. 7 и 8 представлено распределение перемешений хишных птиц по высотным диапазонам. В целом, в осенний период миграция хишных птиц проходит на меньших высотах, нежели в весенний, что можно объяснить более быстрым транзитным перемешением с целью как можно раньше занять гнездовые участки. В этих условиях миграция в пределах исследуемого нами региона осушествляется транзитно - на значительной высоте.

Малые подорлики в весенний периоА летят преимушественно на высотах от 100 Ао 200 м, а осенью их высотное распрелеление более равномерно (рис. 8). Большие подорлики в весенний период придерживаются узкого диапазона высот 350-400 м, т.е. летят в среднем сушественно выше мамых подорликов, а на осенней миграции их высотное распределение идентично таковому малых подорликов (рис. 8). Полевые луни, в отличие от остаиьных виАОв хишных птиц, в весенний сезон летят ниже, нежели осенью: преобладают низкие и средние, реже - умеренные диапазоны - $о 200$ м; осенью же их высотное распрелеление более-менее

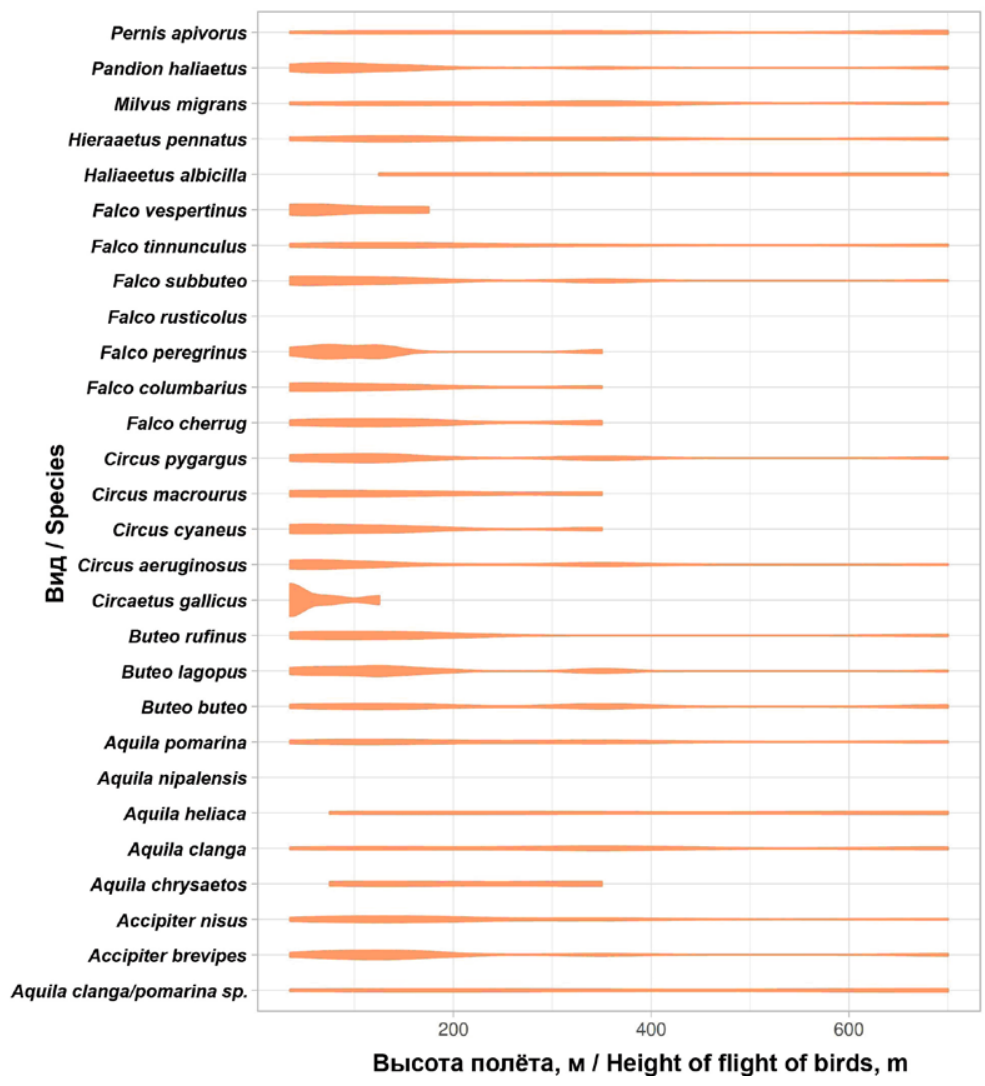

равномерно (рис. 8). Скопы на весенней миграции в равной мере придерживаются всех высотных диапазонов, а осенью преобладают низкие и средние диапазоны - $о$ 150 м (рис. 8). Наибольшая высота миграционных перемешений характерна мля орлана-белохвоста: минимальные значения относятся к высотам более 150 метров. На высоте $а$ о 200 метров - на низких и средних высотах в равной мере происходит перемешение подавляюшего большинства кобчиков, сапсанов, луговых, полевых и большей части степных луней, змееялов, курганников, бамобанов, орловкарликов (осенью - более равномерно) и значительной части дербников. Орлы (род Aquila) равномерно распределены между всеми высотными диапазонами (рис. 7).

Обыкновенный канюк отАаёт предпочтение диапазонам $\Delta о 400$ м, в гораздо меньшей степени птицы летят на высоте более 600 м (последнее справециво преимушественно мяя октябрьских наблюдений транзитных стай). В отличие от обыкновенного канюка, зимняки перемешаются преимушественно на мамых и средних высотах, а перемешения на высотах свыше 400 м является искиючением из правила (рис. 7). Обыкновенные пустельги и осоеды летят равным образом на всех высотных диапазонах (рис. 7). Болотные муни в весенний сезон придерживаются в равной степени всех высотных диапазонов, а в осенний период Аоминируют низкие высоты - $А$ 100 м (рис. 8).

6. Биотопическое распределение регистращий мигрирующих хишных птиц

Анализ биотопического распределения мигрируюших хишных птиц (прежде всего - отАыхаюших птиц и птиц, охотяшихся на миграционных остановках или во время перемешений) даи следуюшую картину. Наиболее важным местообитанием являются открытые ландшафты пойм больших рек (Северский Аонец, Оскол). Аалее следуют (в порядке убывания): сочетание открытых и лесных участков поймы $\rightarrow$ пойма малых водотоков + опушки нагорных $у$ брав + суходольные луга $\rightarrow$ поля, лесные ландшасты пойм + населенные пункты

Рис. 7. Высота миграционных перемешений хищных птиц по наблюдениям в Харьковской области, Украина.

Fig. 7. Migration altitudes of birds of prey in Kharkiv region, Ukraine. 
Рис. 8. Высота перемешений хищных птиц на весенней и осенней миграциях.

Fig. 8. Flight altitude of birds of prey on spring and autumn migrations.

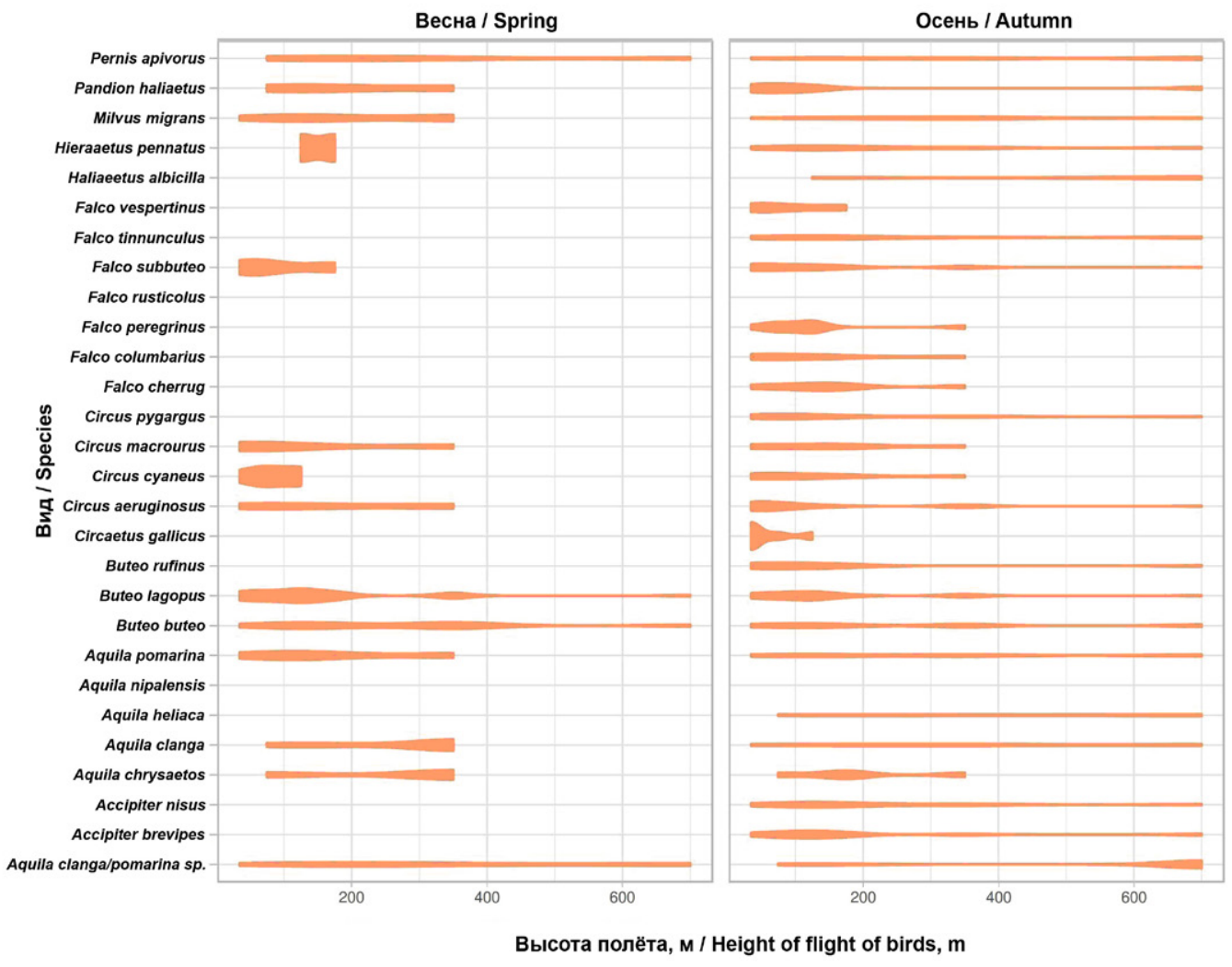

сельского типа + опушки нагорных дубрав $\rightarrow$ поля + суходолы (см. Приложение $2^{93}$ ).

$\mathrm{K}$ наиболее значимым типам биотопов следует отнести открытые и лесные ландшасты обширных пойм, поля и суходомы со степными участками, а также такие сугубо экотонные мандшафты, как сочетания опушек нагорных Аубрав и открытых мандшастов, границы бора и луговых пойм, границы нагорных Аубрав и луговых (реже - лесных) пойм, поймы мамых воАотоков в сочетании с суходолами, полями и опушками нагорных дубрав. Крупные озёра и водохранияиша, наряду с прирусловыми участками больших рек, являются характерным биотопом мяя остановки мигрируюших скоп. К открытым и лесным (приопушечные части) поймам больших рек относятся не менее 50 \% регистраций останавливаюшихся на миграции тювиков европейских и степных муней, около $40 \%$ регистраций полевых куней и $1 / 3$ регистраций орлов-карликов, большая часть регистраций змееяла (второй по значимости биотоп - вырубки в бору и участки старого редкостойного бора) и $100 \%$ регистраций останавливаюшихся на миграциях перепелятников, почти все регистрации могильников и более $50 \%$ регистраций Аербников. Второй по значимости биотоп дербника - поймы мамых рек в сочетании с суходолами и населенные пункты городского типа. На поймы крупных рек приходится почти половина всех регистраций мигрируюших хишных птиц, чаше всего в экотонах лесной и открытой поймы, а также бора и муговой поймы. В экотонах луговых и лесных пойм больших рек отмечено около 2/3 регистраций останавливаюшихся на миграции беркутов.

Поля (часто с вкиючениями степных и суходольнолуговых участков) также являются важным - вторым по значимости биотопом. В этом биотопе отмечены около 40 \% останавливаюшихся на миграциях орлов-карликов, более 40 \% "светлых луней" (степной, полевой, луговой), Ао 1/3 учтенных обыкновенных канюков, зимняков и осоедов, около половины курганников (в экотоне поймы и сухОАОЛьных лугов, экотоны поймы малых рек и нагорных дубрав).

В табл. 6 дано сравнение значимости разных биотопов мия наиболее массовых мигрируюших хишных птиц, а также мия 4 вилов рода настояших орлов. Также приведены сравнения межАу особенностями биотопического распределения транзитных мигрантов и птиц, останавливаюшихся на миграциях. Полученное нами распределение свидетельствует в пользу утверждения, что хишные птицы (за искиючением соколов) стараются на миграционных 
Табл. 6. Биотопическое распределение некоторых видов хищных птиц (транзитные мигранты и птицы, останавливающиеся на миграции) (проценты от обшего количества регистраций).

Table 6. Habitats distribution of some raptor species (transit and stopovering individuals) (presents from the total number of registrations).

\begin{tabular}{|c|c|c|c|c|c|c|c|c|c|}
\hline Биотоп / Habitat & $\begin{array}{r}\text { Pernis } \\
\text { apivorus }\end{array}$ & $\begin{array}{r}\text { Falco } \\
\text { subbuteo }\end{array}$ & $\begin{array}{l}\text { Buteo } \\
\text { buteo }\end{array}$ & $\begin{array}{r}\text { Buteo } \\
\text { lagopus }\end{array}$ & $\begin{array}{l}\text { Buteo } \\
\text { rufinus }\end{array}$ & $\begin{array}{r}\text { Aquila } \\
\text { chrysaetos }\end{array}$ & $\begin{array}{l}\text { Aquila } \\
\text { heliaca }\end{array}$ & $\begin{array}{l}\text { Aquila } \\
\text { clanga }\end{array}$ & $\begin{array}{r}\text { Aquila } \\
\text { pomarina }\end{array}$ \\
\hline $\begin{array}{l}\text { Пойменные луга / Mead- } \\
\text { ows of river valleys }\end{array}$ & $30 / 30$ & $25 / 30$ & $25 / 25$ & $25 / 25$ & $20 / 40$ & $25 / 33$ & $0 / 60$ & $33 / 33$ & $33 / 33$ \\
\hline $\begin{array}{l}\text { Экотоны нагорной } \\
\text { дубравы, редколесий и } \\
\text { заболоченной долины } \\
\text { небольшого водотока } \\
\text { Ecotones of sparse grown } \\
\text { forests, upland oak forests } \\
\text { and boggy valleys of } \\
\text { small rivers; }\end{array}$ & $\leq 5 / \leq 5$ & $25 / 30$ & $\leq 15 / \leq 15$ & $25 / 25$ & $\leq 5 / 0$ & $0 / 33$ & $33 / 33$ & $33 / 33$ & $33 / 33$ \\
\hline $\begin{array}{l}\text { Поля, суходолы и } \\
\text { степные участки, экотоны } \\
\text { этих биотопов / Fields, } \\
\text { steppes, meadows and } \\
\text { ecotones of these habitats }\end{array}$ & $\leq 5 / \leq 5$ & $\leq 5 / \leq 5$ & $\leq 15 / \leq 15$ & $5 / 20$ & $\leq 5 / 0$ & $50 / 33$ & $\leq 5 / \leq 5$ & $20 / 20$ & $20 / 20$ \\
\hline $\begin{array}{l}\text { Экотоны населенного } \\
\text { пункта, открытых } \\
\text { пойменных } \\
\text { местообитаний и } \\
\text { приопушечной части } \\
\text { боровых массивов } \\
\text { Ecotones of settlements, } \\
\text { open floodplains and pine } \\
\text { forests }\end{array}$ & $\leq 5 / \leq 5$ & $\leq 25 / \leq 15$ & $\leq 15 / \leq 15$ & $\leq 5 / 20$ & $30 / 20$ & $25 / \leq 5$ & $33 / \leq 5$ & $\leq 5 / \leq 5$ & $\leq 5 / \leq 5$ \\
\hline $\begin{array}{l}\text { Нагорные дубравы с } \\
\text { заболоченными балками } \\
\text { Upland oak forests with } \\
\text { bogs in the ravines }\end{array}$ & $\leq 5 / \leq 5$ & $\leq 5 / \leq 5$ & $\leq 5 / \leq 5$ & $\leq 5 / \leq 5$ & $\leq 5 / 0$ & & $\leq 5 / \leq 5$ & $\leq 5 / \leq 5$ & $\leq 5 / \leq 5$ \\
\hline $\begin{array}{l}\text { Населенные пункты } \\
\text { городского типа / Towns }\end{array}$ & $\leq 5 / \leq 5$ & $\leq 5 / \leq 5$ & $\leq 5 / \leq 5$ & $\leq 5 / \leq 5$ & $\leq 5 / 0$ & & & $\leq 5 / 15$ & $\leq 5 / \leq 5$ \\
\hline $\begin{array}{l}\text { Большие озера и } \\
\text { водохранилиша / Large } \\
\text { lakes and reservoirs }\end{array}$ & $\leq 5 / 0$ & $\leq 5 / \leq 5$ & $\leq 5 / 0$ & $\leq 5 / 0$ & $\leq 5 / 0$ & $\leq 5 / 0$ & $\leq 5 / 0$ & $\leq 5 / 0$ & $\leq 5 / 0$ \\
\hline $\begin{array}{l}\text { Поля и прочие открытые } \\
\text { агроландшасты / Fields } \\
\text { and other open agrarian } \\
\text { landscapes }\end{array}$ & $\leq 5 / \leq 5$ & $\leq 5 / \leq 5$ & $\leq 5 / \leq 5$ & $\leq 5 / \leq 5$ & $\leq 5 / 0$ & $\leq 5 / 0$ & $\leq 5 / 0$ & & $\leq 5 / 0$ \\
\hline $\begin{array}{l}\text { Экотон открытых } \\
\text { агроландшастов и } \\
\text { лиственных лесов } \\
\text { Ecotones of open agrarian } \\
\text { landscapes (fields) and } \\
\text { deciduous forests }\end{array}$ & $\leq 5 / \leq 5$ & $\leq 5 / \leq 5$ & $\leq 5 / \leq 5$ & $\leq 10 / \leq 10$ & $30 / 20$ & & $\leq 5 / 0$ & $\leq 5 / \leq 5$ & $\leq 5 / \leq 5$ \\
\hline $\begin{array}{l}\text { Экотоны степных } \\
\text { участков, полей и } \\
\text { заболоченных долин } \\
\text { небольших рек } \\
\text { Ecotones of fields, } \\
\text { steppes and boggy val- } \\
\text { leys of small rivers }\end{array}$ & $40-50 / 50$ & $\leq 5 / \leq 5$ & $\leq 10 / \leq 10$ & $\leq 5 / \leq 5$ & $20 / 0$ & $\leq 5 / \leq 5$ & $\leq 5 / 0$ & $\leq 5 / \leq 5$ & $\leq 5 / \leq 5$ \\
\hline
\end{tabular}

остановках избегать населенных пунктов, а также концентрируются (за искиючением трех видов канюков) в мандшастах, представленных в основном экотонами открытых и лесных биотопов, преимуше- ственно в долинах рек (как малых, так и больших).

Более 70 \% всех регистраций мигрируюших птиц (как транзитных, так и останавливаюшихся на миграции) приходится 
на экотоны основных местообитаний, а именно:

- сочетания лесных и открытых пойм,

- опушек нагорных Аубрав, пойм мамых водотоков и открытых мандшафтов (сухоАОлы, поля),

- открытых пойм и опушек бора с участками ольсов.

Таким образом, ммя мигрируюших хишных птиц жизненно важными оказываются поймы крупных рек и их окраины - на границе с боровой террасой, а также опушки нагорных дубрав, особенно - при наяичии в непосреАственной близости от последней таких элементов рельеса, как Аолины малых рек.

Анамиз биотопического распределения (корреляции регистраций особей разных видов с определенным типом биотопа) показал сильную положительную корремяцию распределения зимняка и обыкновенного канюка ( $T=0,27, p$-value $=0,005)$. Таким образом, биотопическое распремеление обоих видов фактически идентично.

Таковы же результаты сравнения биотопического распределения осоела и обыкновенного канюка $(T=0,27, p$-value $=0,005)$.

Сушественная положительная корремяция выявлена при сравнении биотопического распределения обыкновенного канюка и орла-карлика $(T=0,45$, $p$-value $=0,0001)$.

Анамиз биотопического распределения орла-карлика и подорликов показал, что нет значимой положительной корреляции ( $T=0,20, p$-value $=0,17)$.

Аля орла-карлика наиболее значимыми биотопами являются открытые (луговые) поймы; экотоны ольсов, суходолов и опушек дубрав, редколесья; в меньшей степени - экотоны лесной и луговой поймы. Аия подорликов значимыми биотопами являются: экотоны ольсов, суходОлов и опушек Аубрав; нагорные дубравы и заболоченные балки в них; экотоны суходолов и открытых агроландшастов (преимушественно убранных полей подсолнечника и пшеницы); экотоны лесной поймы и облесенного склона коренного берега; экотоны открытой (луговой) и облесенной поймы; лесная пойма с небольшими болотинами и куговинами, а также старицами.

Не искиючено, что результаты сравнения биотопического распределения орла-кармика и подорликов вызваны сушественной разницей численности особей в выборке по орлу-карлику и подорликам.
Пара видов большой подорлик и мамый подорлик также не показала намичие значимой корреляции $(T=0,24$, $p$-value $=0,13)$ : мля малого подорлика наиболее важными биотопами определены экотоны ольса, суходола и нагорной $ы$ бравы (опушка), экотоны открытой и лесной поймы, луговая пойма, населенные пункты (их перисерия) разных типов, граница поймы и бора, экотоны лесной поймы и облесенных скионов коренного берега (в т.ч. вблизи населённых пунктов). Аия большого подорлика преобмахаюшими биотопами были: нагорные Аубравы с заболоченными балками, бомотные массивы 3-4 террас речных мин, экотоны ольса, суходола и нагорной дубравы (опушка), экотоны бора и поймы (открытой и лесной), лесная пойма, ольсы, поля.

Предпочитаемыми биотопами полевого луня являются поля, степные участки, пойменные куга и болота, лесные поляны, болота 3-4 террас Аолин крупных рек. Аля лугового луня это, соответственно, пойменные луга и поля, реже - степные участки, а м^я степного луня - пойменные муга, болота 3-4 террас Аолин крупных рек, степные участки и, в меньшей степени, поля. Наиболее схожи в биотопическом распределении полевой и степной муни, менее схожи степной и муговой, а парой наименее схожих виАОв являются луговой и полевой луни. В целом, полевые луни на миграционных остановках тяготеют к более увлажненным и остепненным биотопам, а также к небольшим участкам открытых местообитаний в лесах; степные луни - к остепненным участкам и открытым болотам посреди степей и агроландшастов, а луговые луни - к разным открытым ландшастам, преимушественно - обширным пойменным лугам (Аолины крупных рек) и полям (агроландшаст).

Анализ биотопического распределения орлов-карликов, зимняков, обыкновенных канюков, подорликов (малые и большие, а также неопределенные $\Delta$ в вила), "светАых" муней и осоедов в осенний и весенний сезоны показаи, что фактически мия всех сравниваемых пар видов установлено большее сходство занимаемых биотопов в осенний сезон по сравнению с весенним. Осенью также шире диапазон используемых биотопов.

Полевой кунь в весенний сезон чаше встречается в заболоченных балках с луговинами в нагорных дубравах, а также 
Скопа (Pandion haliaetus), национальный природный парк "Гомольшанские леса". Фото С. Витера.

Osprey (Pandion haliaetus), National nature park "Gomilshansky Lisy". Photo by S. Viter.

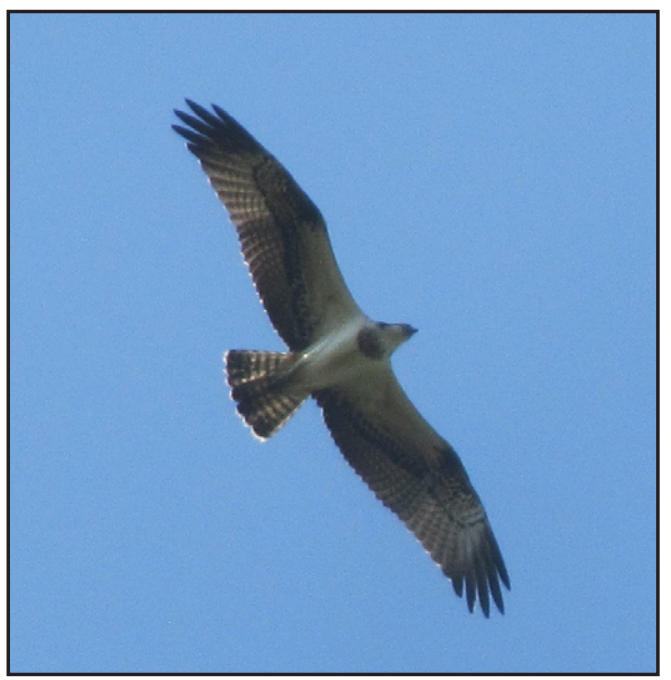

в экотонах нагорных дубрав и открытых местообитаний, включая населенные пункты сельского типа; в осенний период основные биотопы локализованы в экотонах крупных озёр или водохранилищ и опушек боров, населенных пунктов и техногенных ландшастов. ^уговые луни весной отмечены преимушественно на окраинах населенных пунктов и в экотоне нагорной дубравы (опушка), суходола и редколесий (включая старые сады); осенние встречи чаше локамизованы в различных экотонах месных и открытых ландшафтов, особенно - пойм и полей. Степные куни в весенний сезон отдают предпочтение Аолинам малых водотоков в экотоне открытых суходолов и нагорной дубравы, окраинам населенных пунктов, экотону открытой и облесенной поймы крупных рек; осенью вид также тяготеет к Аолинам малых водотоков, но в более открытых - суходольно-степных местообитаниях, а также к болотам 3-4 террас Аолины крупной реки, к степным ландшасртам в сочетании с полями, опушкам боров.

Орлы-карлики в весенний период предпочитают опушки нагорных Аубрав, поАорлики же - открытые, преимушественно пойменные, местообитания; осенью размичия межАу видами более сглажены орёл-карлик широко использует открытые и экотонные пойменные местообитания, а у подорликов увеличивается разнообразие биотопов.

МежАу орлом-карликом и обыкновенным канюком различия в использовании биотопов сводится к гораздо более широкому спектру таковых у второго вида; сезонные различия в использовании биотопов обыкновенными канюками, в общем, несушественны и сводятся к большей Аоле суходолов и опушечных местообитаний, важных в осеннее время.

Биотопическое распределение осоелов и канюков очень схоже в осенний сезон, но имеет рял сушественных различий в весенний. Например, весной значимыми мля осоела являются такие биотопы, как экотон полей и нагорных дубрав - опушка, поля, а также боры; в осенний сезон эти биотопы не играют сушественной роли, для канюка же они не являются значимыми и в весенний период. Канюки заметно чаше, нежели осоеды, используют открытые участки внутри лесных массивов (вырубки, поляны в лесу, берега лесных озёр и пр.).

Биотопические предпочтения обыкновенного канюка и зимняка, как было сказано выше, почти идентичны. При сравнении сезонных отличий можно увидеть, что осенью такое сходство усиливается еше больше. ОАнако в выборе биотопов в весенний сезон есть ряд сушественных отличий межАу этими видами. В целом, в весенний сезон м^я обыкновенного канюка более значимыми являются поля, степные участки, лесные массивы. Аیя зимняка предпочтения смешены в область экотонов суходольных лугов, лесов (преимушественно опушки нагорных $\Delta у$ брав) и пойм малых водотоков, а также экотонов опушек и населенных пунктов, луговых пойм и суходольных лугов, открытых пойменных ландшафтов и полей, боровых массивов с вырубками и полянами.

\section{7. Динамика численности, годовые колебания}

На рис. 9 приведены данные о колебаниях численности разных видов по годам.

Численность большого и малого подорлика мало менялась по годам, максимум численности второго вида был в 2007 г., когАа отмечена миграция около 20 \% птиц, учтённых во все годы наблюдений. Могильник также является регумярным малочисленным мигрантом, не отмечен в 2016 г. Беркуты отмечены на миграции в 2004, 2005, 2010, 2012 и 2014 гг., а степные орлы - только в 2011 и 2016 гг. (регистрация птицы в 2015 г., возможно, относится к летуюшей или кочуюшей).

Численность обыкновенного канюка была максимаиьной (10-20\% от количества отмеченных птиц) в 2015, 2014, 2016 и 2010 гг. (года расположены по убыванию численности), а минимаиьной - в 2013 г. 
Также в 2013 г. (равно, как и в 2012 г.) был минимум численности мигрируюших зимняков, а их максимум пришелся на 2010 г. (20\% от учтенных птиц) и 2015 г. (30\% учтенных за все годы птиц).

Курганники в сезоны осенних миграций отмечены еАинично, однако в 2011 и, особенно, 2012 и 2014 гг. численность вида резко выросла. В сезоны 2013, 20152016 гг. мы не располагаем наблюдениями мигрируюших курганников.

Минимум численности осоедов на осенних миграциях был в 2008 и 2009 г. (в каждый год - менее $10 \%$ от учтенных за все годы птиц), в 2010 г. - значительный рост численности, в Аальнейшем - стабильные показатели, а в 2016 г. - максимум численности вида на миграции - не менее $25 \%$ от обшего количества отмеченных за все годы осоедов.

Более 80 \% регистраций мигрируюших кобчиков относятся к сезонам 20142016 гг., что, нарялу с появлением 3-4 новых участков в регионе, абонируемых
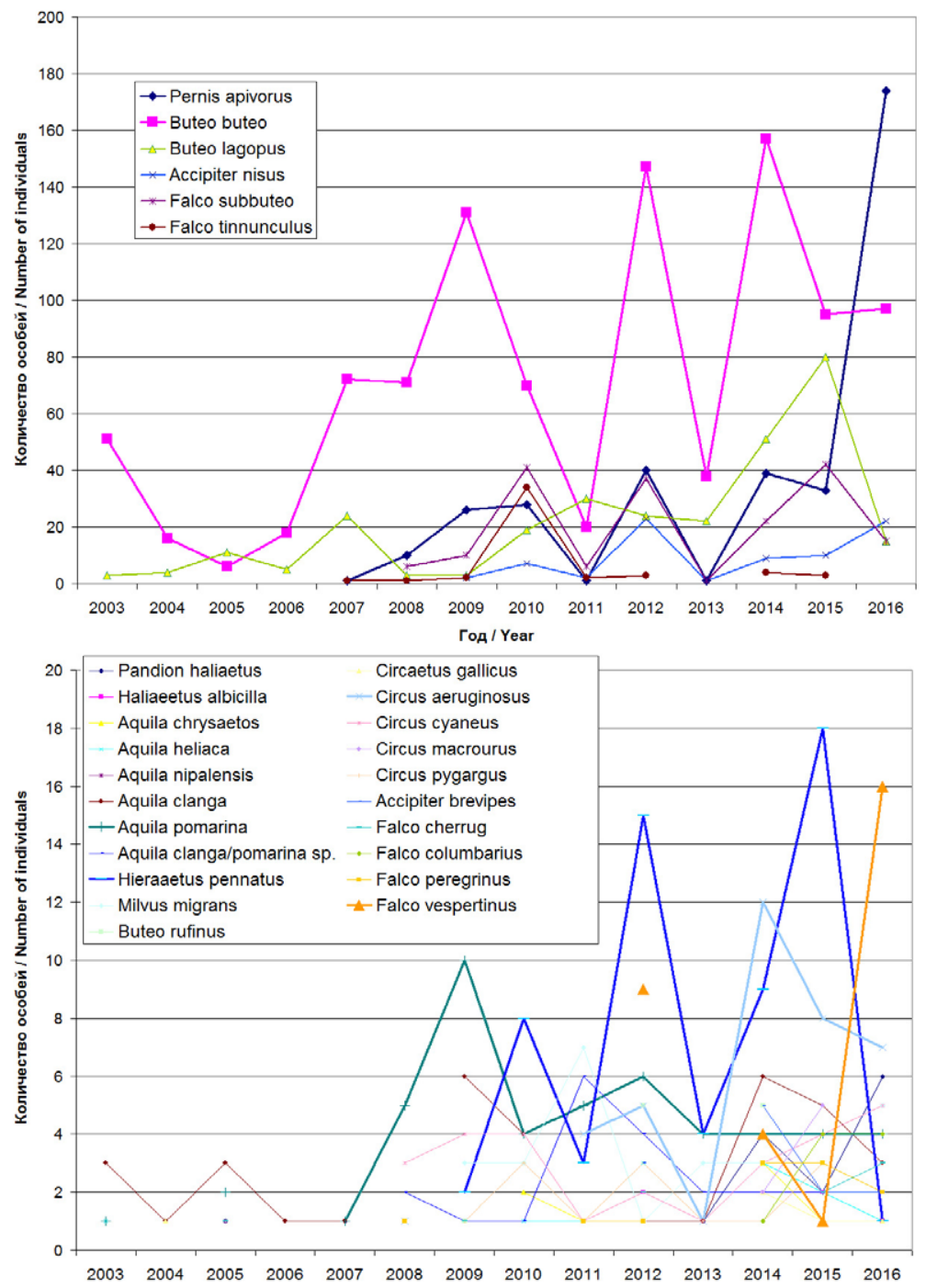

Год/Year на протяжение всего гнездового сезона, говорит в пользу обшего роста численности популяции вида в Восточной Европе после Алительной депрессии.

Аля чёрного коршуна минимум численности мигрируюших птиц пришелся на 2012-2014 гг., после чего ее показатели вышли на прежний уровень.

Максимум численности мигрируюших орАов-карликов отмечен в 2012 и 2015 гг., минимум - в 2013 и 2016 гг., разница между годами высокой численности мигрируюших орлов-карликов и годами низкой их численности достигает 3-5 крат. На годы максимума численности на 1 сезон прихоАится более 30 \% от всех регистраций вида за весь период наблюдений.

Численность полевых муней в период миграции достигла максимума в 2014 и 2016 гг., на каждый сезон приходится $25 \%$ всех регистраций. В Аругие годы вил отмечали регулярно, но со стабильно низкой численностью.

Около $70 \%$ регистраций мигрируюших степных луней приходится на 2014 и 2015 гг., а в 2016 г. численность птиц сократилась $А$ полного отсутствия регистраций на осенней миграции.

Максимальная численность куговых куней - 2015 г. (почти половина всех регистраций), в меньшей степени 2008, 2009 и 2012 гг.

Численность болотных муней была максимальна (20-25 \% от всех регистраций) в 2014 и 2015 гг., значительно сократившись (почти в 2,5 раза) в 2016 г. В 2012 г. отмечена относительно высокая численность, а в 2013 - Аепрессия. Очень низкой численность вида была в период до 2009 года вкиючительно. Такая динамика, в целом, синхронна с слуктуацией численности Аругих виАов муней и, в значительной степени, с Аинамикой численности мигрируюших канюков (обыкновенный канюк и зимняк).

Как год депрессии численности многих мигрантов, прежле всего миосрагов (куни, канюки), можно охарактеризовать 2013 г.

Чуть менее половины регистраций (40 \%) мигрируюших змееялов приходится на

Pис. 9. Аинамика численности мигрирующих хищных птиц по годам (вверху - Аоминанты).

Fig. 9. Population dynamics of migrant birds of prey for 14 years (at the top - dominant species). 
2015 г., вих отмечен нерегулярно (2007, 2011, 2012, 2014, 2015 гг.).

Годом максимума численности перепелятника стал 2012 г.: на осенний сезон миграции в этот гоА приходится около 1/3 всех регистраций. Высока численность была и в сезон 2016 г. - на уровне около $20 \%$ регистраций, а крайне низка (единичные регистрации) - в 2013 г. $\Delta$ о 2008 г. наблюдения миграции этого вида не носили систематический характер и многие регистрации нами позже были расценены как такие, которые скорее можно отнести к наблюдениям местных птиц. В 2009-2011 и в 2014-2015 гг. численность вида была приблизительно на одном уровне.

Европейские тювики отмечены нами в период осенних миграций в 2011, 2012, 2014-2016 гг., а весной - в 2007 г.

Скопа отмечена регулярно, в числе $\Delta о$ 10 особей/сезон. На 2016 г. пришелся резкий рост численности вида, когАа только через территорию национаиьного природного парка "Гомольшанские леса" мигрироваяи не менее 16 особей.

Минимальной численность обыкновенной пустельги была в период Ао 2007 г. вкцючительно, а также в сезон осенней миграции 2016 г.

Максимум численности чеглоков пришелся на 2011, 2012 и 2015 гг. - по $25 \%$ всех регистраций. Снижение численности $\Delta$ о $10 \%$ от всех регистраций - в 2014 и 2016 гг. Аепрессия численности отмечена в период до 2009 г. вкиючительно, а также в 2013 г.

Баиобаны отмечены нерегулярно с 2011 г.: 2011, 2012, 2015, 2016 гг. Ао 2011 г. нами этот виА в период миграций не отмечен.

Обшими закономерностями динамики численности мигрируюших хишных птиц можно назвать:

- относительную стабильность численности крупных видов с мало специамизированным питанием;

- рост численности змееяла в 2015 г. и скопы в 2016 г.;

- численность осоеда возрастала двумя этапами - в 2009-2010 гг. и в 2016 г., оставаясь относительно стабильной в период с 2010 г. по 2015 г., не отмечено Аепрессии в 2013 г.;

- численность миосрагов (канюки, Ауни) была максимамьна в 2014 и 2015 гг., пошла на спал в 2016 г., а депрессия отмечена в 2013 г.; Аостаточно высокие показатеми - в 2011 и 2012 гг.;

- численность орнитосрагов можно охарактеризовать относительно стабильной, пик численности перепелятника приходится на 2012 и 2016 гг., а чеглока - на 2012 г.; интересно отметить значительное сокрашение численности этих видов в сезон 2013 г.;

- годами максимаиьной численности мигрируюших хишных птиц были 2014 и 2015 гг., в меньшей степени - 2010-2012 гг. и 2016 г. (50-75\% от количества регистраций мигрируюших хищных птиц в годы максимальной численности), а обшая депрессия - в 2005-2006 гг. и в 2013 г., когаа отмечено 10-15\% от численности мигрантов в годы максимаяьной численности.

Анамиз Аинамики численности разных виАОв хишных птиц показая отсутствие значимой корреляции межАу ними (например, соотношение динамики численности осоеда и обыкновенного канюка - $T=0,55$, $p$-value $=0,029$, обыкновенного канюка и зимняка - $T=0,21, p$-value $=0,295$, обыкновенного канюка и орла-карлика - $T=0,21$, $p$-value $=0,458$, орла-карлика и подорликов $-\tau=0,20, p$-value $=0,503)$.

Анаииз корреляции межАу динамикой численности особей (регистрации особей) и Аинамикой числа регистраций показац, что есть значимая положительная корреляция межАу Аинамикой численности особей и Аинамикой количества регистраций. Иными словами, численность групп (и соотношение групп разной численности) в целом является стабильной относительной векичиной. Численность определенного вида может изменяться, но процент регистраций, прихоАяшихся на одиночек, пары, группы из 3-х особей, из 4-х особей и пр. остаётся маио меняюшимся из года в год. В качестве примера приведены данные мия 4-х видов: обыкновенный канюк: $T=0,82, p$-value $=4,028$; зимняк: $T=0,89, \quad p$-value $=0,1522$; осоед: $T=0,95, \quad p$-value $=0.0003$; чеглок: $T=0,94$, $p$-value $=0.0005$.

\section{8. Киючевые территории (в пределах} региона) мя мигрирующих хищных птиц. Рекоменцации к охране мигрирующих хищных птиц

Маршрутные учёты хишных птиц в сезон осенних и весенних миграций, а также наблюдения остановок мигрируюших птиц в пределах стационаров позволили вылелить рял территорий, имеюших важное значение как места остановки мигрируюших хишных птиц. К киючевым территориям отнесены такие:

- на которых отмечено пребывание всех редких видов из Красной книги Украины (Червона книга..., 2009), 


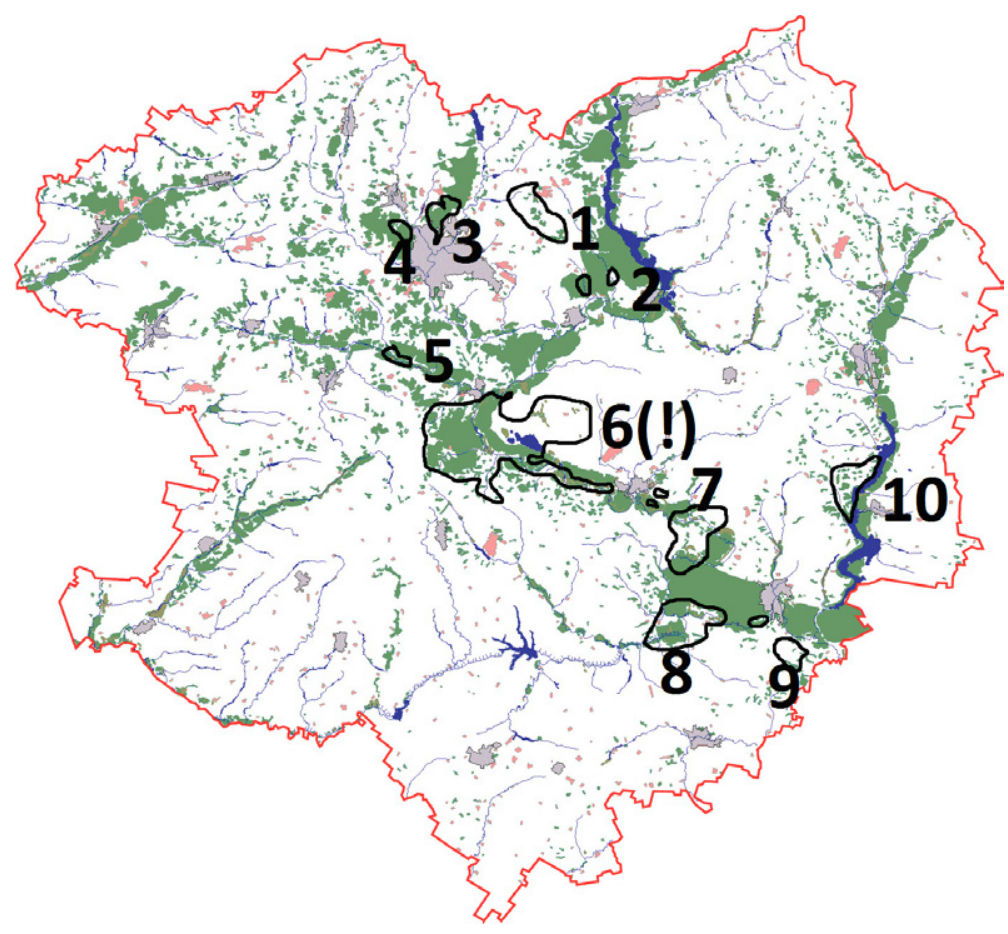

- остановка на миграции групп осоедов и канюков с численностью более 10 особей,

- численность останавливаюшихся на миграции хишных птиц более, чем в 2 раза превышает таковую на Аюбой из иных (не киючевых) территорий.

Нами выделено 10 территорий, две из которых состоят из 2-х киастеров, а еше одна вкиючает 3 киастера (рис. 10).

$\Delta$ ве вылеленные территории расположены на водоразделах и охватывают как плакоры, так и верховья балок со степной растительностью и фрагментами дубрав. ОАна из таких территорий (рис. 10-1) расположена на южных отрогах Среднерусской (Восточноевропейской) возвышенности (окрестности с. Петровка Харьковского района), вторая (рис. 10-9) - на отрогах $\triangle$ онецкой возвышенности (окрестности с. Камянка Изюмского района).

В Аолине небольшой реки расположены Аве территории: Аолина р. Мжа (пойменная и вторая - боровая - террасы) межАу г. Мереса и с. Тимченки (Харьковский / Змиевский амм. районы) (рис. 10-5); фрагменты долин р. Тетлега и Великая Бабка в Чугуевском и Печенежском районах (рис. 10-2).

ОАна территория охватывает срагменты дубовых лесов, степные ландшафты и поля на правом берегу р. Оскол (точнее - на западном берегу Краснооскольского водохранилиша) в пределах Боровского района, у с. Гороховатка (рис. 10-10).

$\Delta$ ве территории представлены крупными фрагментами дубовых водораз-
Рис. 10. Киючевые территории миграционных остановок хишных птиц в Харьковской области, Украина.

Fig. 10. Key territories for migration stopovers for in Kharkiv region, Ukraine.

дельных лесов у границ города Харькова (рис. 10-3,4), на карте обозначены цисрами 3 и 4.

Остаиьные три территории целиком лежат в пределах Аолины самой большой реки региона - Северского Аонца. Эти участки наиболее разнообразные в плане ландшафтной структуры и вкиючают как пойменные куга разных типов, террасные боры, участки песчаных степей, дубравы поймы и коренного берега, болота лесные (ольсы) и травяные, озёра-старицы, так и степные участки коренного берега, поля, болота 3-4 террас.

\section{Рекоменцации по охране мигрирую-} щих хищных птиц

Важными составляюшими охраны мигрируюших хишных птиц являются территориальная охрана киючевых мест остановки и птицезашитные мероприятия на АЭП.

1. Оснашение птицезашитными полимерными изоляторами или изолированным кабелем АЭП 6-10 кВ необходимо прежле всего в прелелах Змиевского, Харьковского, Барвенковского и Зачепи^овского районов, а также Краснооскольского и Краснопавловского районов и в ралиусе 5 км вокруг них.

2. Расширение сети ООПТ в Харьковской области:

- расширение территории Национаиьного природного парка "Гомольшанские леса" (рекомендации вкиючены в Аействуюший ныне «Проект организации территории НПП "Гомольшанские леса"); реаиизация пиана позволит взять под охрану такие территории, как вся плошадь участков № 6, № 5 и большую часть участка № 7 (см. рис. 10);

- расширение территории Регионаиьного ландшастного парка "Изюмская лука" и предоставление этой территории статуса Национацьного природного парка; реаизация проекта позволит обеспечить охрану территории № 8 и южной части территории № 7 (см. рис. 10);

- создание Национамьного природного парка "Барвенковские степи", который позволит обеспечить охрану части территории № 8 и б.ч. территории № 9 (см. рис. 10); все соответствуюшие Аокументы поданы в просильное министерство; 
- создание Региональных ландшасттных парков "Харьковский лесопарк" и "Петровские балки"; реализация этих проектов позволит обеспечить охрану участков № 1 и № 3 (см. рис. 10);

3. Создание особо ценных участков охранных зон вокруг гнёзд хищных птиц в пределах территорий № 2 и № 4 (см. рис. 10), перечень которых и соответствуюшие материаиы переданы в Министерство экомогии и природных ресурсов Украины, а также Государственное агентство лесных ресурсов Украины (эта работа выполнена при поццержке программы мамых грантов фонда Русрсорда (Viter, 2017).

4. Ограничение охоты в пределах и в радиусе 5 км от границ Краснооскольского и Краснопавловского водохранилиш, в пределах Печенежского рыбхоза, в пределах Аиманской озерной системы (урочиша "Андреевский бор", "Андреевский Сухой Аиман", "Озеро Очеретоватое", "Озеро Чайка", "Камышеватое», "Сухой Лиман" и "Горелая Аолина"), а также на территории и в 3-километровой зоне вокруг авиаполигона у с. Благодатное (Змиевский район).

\section{Выводы}

1. Из обшей выборки регистраций мигрируюших хишных птиц видом-доминантом является обыкновенный канюк (Buteo buteo) - 451 регистрация (32,4 \% всех регистраций мигрируюших птиц). К субАоминантам можно отнести зимняка - 201 регистрация (14,43\%), а также осоена (Pernis apivorus) - 140 регистраций (10,05\%) и чеглока (Falco subbuteo) - 147 регистраций (10,55\%).

2. Аия всех видов Аневных хишных птиц в районе исследования наиболее характерным является перемешение в одиночку, гораздо реже - небольшими группами и достаточно редко - стаями. Такая картина разительным образом отличается от наблюдаемого в "бутылочных горлышках" миграционных коридоров.

3. Наиболее скионными к участию в образовании смешанных групп мигрантов можно назвать малого подорлика, $20 \%$ всех мигрируюших особей которого отмечены в таких группах. Среднее число особей в мультивидовых группах составля-

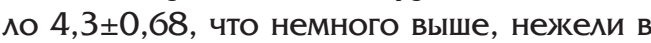
моновидовых группах $(3,66 \pm 0,65)$, но эти различия статистически недостоверны.

4. Аия большинства видов отмечено преоблахание транзитных мигрируюших особей нах останавливаюшимися на ми- грации: таких 18 видов из 27, или 66,6 \%. Например, около 2/3 из учтенных канюков и орлов-карликов, $90 \%$ осоелов, $60 \%$ беркутов, европейских тювиков и чеглоков, 70 \% обыкновенных пустельг и могильников и $65 \%$ малых подорликов могут быть отнесены к транзитным мигрантам.

5. Периодами наиболее интенсивных миграционных перемешений можно назвать вторую половину августа, сентябрь, первую и вторую декацу октября, а также последнюю декацу февраля и апрель (начало - средина месяца).

6. Преоблахаюшим направлением осенних миграций является юг, юго-восток и юг-восток-юг, реже встречаются запацное, юго-запацное и прочие направления румбов секции "запад - юг - восток». Преобладаюшими направлениями весенних миграционных перемешений, согласно нашим наблюдениям, являются северовосток.

7. Более $70 \%$ всех регистраций мигрируюших птиц (как транзитных, так и останавливаюшихся на миграции) приходится на экотоны основных местообитаний, а именно:

- сочетания лесных и открытых пойм,

- опушек нагорных Аубрав, пойм мамых водотоков и открытых ландшастов (сухоАОлы, поля),

- открытых пойм и опушек бора с участками ольсов.

Таким образом, мия мигрируюших хишных птиц жизненно важными оказываются поймы крупных рек и их окраины - на границе с боровой террасой, а также опушки нагорных дубрав, особенно - при наличии в непосредственной близости от последней таких элементов рельесра, как молины малых рек. Отмечено сушественное отличие в предпочитаемых биотопах малого и большого подорлика, подорликов и орла-карлика, некоторое отличие - среди видов группы светлых муней (минимальное отличие межАу степным и полевым лунями, максимальное - межАу луговым и полевым); очень сходное биотопическое распределение канюков, зимняков, орлов-карликов и осоедов.

8. Общими закономерностями динамики численности мигрируюших хишных птиц можно назвать:

- относительную стабильность численности крупных вилов с мамо специамизированным питанием;

- рост численности змееяла в 2015 г. и скопы в 2016 г.; 
- численность осоела возрастала двумя этапами - в 2009-2010 гг. и в 2016 г., оставаясь относительно стабильной в период с 2010 г. по 2015 г., не отмечено депрессии в 2013 году;

- численность миофрагов (канюки, луни) была максимальна в 2014 и 2015 гг., пошла на спац в 2016, а депрессия отмечена в 2013 г.; достаточно высокие показатели - в 2011 и 2012 гг.;

- численность орнитосрагов можно охарактеризовать относительно стабильной, пик численности перепелятника отмечен в 2012 и 2016 гг., а чеглока - в 2012 г.; интересно отметить значительное сокрашение численности в сезон 2013 года;

- годами максимальной численности мигрируюших хищных птиц были 2014 и 2015 гг., в меньшей степени - 2010-2012 гг. и 2016 г. (50-75 \% от количества регистраций мигрируюших хишных птиц в годы максимальной численности), а общая депрессия - в 2013 г. и в 2005-2006 гг., ког$\Delta$ а отмечено 10-15 \% от численности мигрантов в годы максима^ьной численности.

\section{Благоцарности}

Автор выражает искреннюю благодарность О.В. Прилуцкому, при содействии которого появилась возможность проведения обработки и анализа материалов в среде R.

Автор выражает благодарности С.В. Влашенко и Е.А. Яцюку, а также комективу юных натуралистов Харьковского зоопарка и "Фельдман-экопарка" и сотрудникам отдела науки и мониторинга Национального природного парка «Гомольшанские леса" за оказание технической помощи в маршрутных учётах (и учётах на точках) мигрируюших хищных птиц.

\section{Митература}

Кабаков Р.И. R в Аействии: анаииз и визуаиизация Аанных в программе R / Пер. с англ. П. Волковой. Москва: $\triangle$ МК Пресс, 2014. 588 с. [Kabаkov R.I. R in action: analysis and visualization of data in the R program. Translation from English by P.Volkova. Moskow: DMK Press, 2014: 1-588 (in Russian).]. URL: http://kek.ksu.ru/eos/WM/Kabacoff2014ru.pdf Аата обрашения: 25.10.2017.

Карякин И.В. Большой подорлик по имени Киангуша из Алтайского края третий раз благополучно добрался до места зимовки в Пакистане. - Российская сеть изучения и охраны пернатых хишников. 2016. [Karyakin I.V. А Greater Spotted Eagle named Klangusha from the Altai Kray arrived safely for the third time to the wintering place in Pakistan. - Russian Raptor
Research and Conservation Network. 2016 (in Russian).]. URL: http://rrrcn.ru/archives/27207 Аата обрашения: 25.10.2017.

Комплексний атлас України. Київ: Укргеодезкартограсрія, 2005. 96 с. [Integrated atlas of Ukraine. Kyiv, 2005: 1-95 (in Ukrainian).].

Сомов Н.Н. Орнитологическая фауна Харьковской губернии. - Харьков, 1897. 680 с. [Somov N.N. Ornithological fauna of Kharkiv region. Kharkiv, 1897: 1-680 (in Russian).].

Червона книга України. Тваринний світ/ за ред. І.А. Акімова. Київ: Глобалконсалтинг, 2009. 600 c. [Red Data Book of Ukraine. Animals /I.A. Akimov Ed. Kiev, 2009: 1-600 (in Ukrainian).]. URL: http://redbook-ua.org/files/ Red_book_animals_2009.zip Аата обрашения: 25.10.2017.

Шамрай С.М., Захорожний К.М. Біологічні дослілження. Планування і проведення. Харків: Видавнича група "Основа", 2010. 112 с. [Shamrai S.M., Zadorojniy K.M. Biological investigations. Planning and implementation. Kharkiv, 2010: 1-112 (in Ukrainian).]. URL: http://mycology.univer.kharkov.ua/wp-content/ uploads/2017/04/SHamraj-and-Zadorozhnyj2010-Biologichni-doslidzhennya.-Planuvannya-i-provedennya.pdf $\triangle$ ата обрашения: 25.10.2017.

Allen D., DeCandido $R$. Raptor Migration in Thailand. - thaibirding.com. 2007. URL: http:// www.thaibirding.com/features/raptormigration. htm Аата обращения: 25.10.2017.

BRC. Migration Count Data. - Batumi Raptor Count. 2017. URL: http://www.batumiraptorcount.org/raptor-migration/migration-countdata $\triangle$ ата обрашения: 25.10.2017.

Birding Cadiz Province. TARIFA - Migration Watchpoints (off the N340 Algeciras-Tarifa road) Introduction - i) Raptor Passage. - Birding Cadiz Province . 2017. URL: https://birdingcadizprovince.weebly.com/2---tarifa.html $\triangle$ ата обрашения: 25.10.2017.

Fergusson-Lees J., Christie D. Raptors of the World. A field guide. London: Christopher Helm, 2006: 1-320.

Newton I. The migration Ecology of Birds. London: Acad. Press. 2008: 1-976.

R Core Team. R: A language and environment for statistical computing. Foundation for Statistical Computing. 2016. URL: https://www.R-project.org Аата обрашения: 25.10.2017.

Viter $S$. To Establish a Protected Zones around the Raptors Nests - The Way to Preserve both Key Raptors Populations and Biodiversity Generally. - The Rufford Foundation. 2017. URL: https://www.rufford.org/projects/stanislav_viter $\Delta$ ата обрашения: 25.10.2017.

Wei T., Simko V. Corrplot: Visualization of a Correlation Matrix. R package version 0.77 . 2016. URL: https://CRAN.R-project.org/ package $=$ corrplot $\Delta$ ата обрашения: 25.10.2017.

Wickham H. ggplot2: Elegant Graphics for Data Analysis (Use R!). $2^{\text {nd }}$ ed. New York: Springer, 2009: 1-1260. 